\title{
Solid-State Nuclear Magnetic Resonance Measurements of HIV Fusion Peptide to Lipid Distances Reveal Intimate Contact of $\beta$ Strand Peptide with Membranes and Close Proximity of the Ala-14 to Gly-16 Region with Lipid Headgroups
}

\author{
Wei Qiang $\ddagger$, Jun Yang $\S$, and David P. Weliky ${ }^{\star}, \ddagger$ \\ $\$$ Department of Chemistry, Michigan State University, East Lansing, MI 48824 \\ $\S$ Department of Molecular Cardiology, Lerner Research Institute, Cleveland Clinic Foundation, Cleveland, \\ $\mathrm{OH} 44195$
}

\begin{abstract}
Human immunodeficiency virus (HIV) infection begins with fusion between viral and host cell membranes and is catalyzed by the HIV gp41 fusion protein. The $20 \mathrm{~N}$-terminal apolar residues of gp41 are called the HIV fusion peptide (HFP), interact with the host cell membrane, and play a key role in fusion. In this study, the membrane location of peptides which contained the HFP sequence AVGIGALFLGFLGAAGSTMGARS was probed in samples containing either only phospholipids or phospholipids and cholesterol. Four HFPs were examined which each contained ${ }^{13} \mathrm{CO}$ labeling at three sequential residues between G5 and G16. The ${ }^{13} \mathrm{CO}$ chemical shifts indicated that HFP had predominant $\beta$ strand conformation over the labeled residues in the samples. The internuclear distances between the HFP ${ }^{13} \mathrm{COs}$ and the lipid ${ }^{31} \mathrm{Ps}$ were measured using solid-state nuclear magnetic resonance rotational-echo double resonance experiments. The closest ${ }^{13} \mathrm{CO}-{ }^{31} \mathrm{P}$ distances of 5-6 A were observed for HFP labeled between A14 and G16 and correlated with intimate association of $\beta$ strand HFP and membranes. These results were confirmed with measurements using HFPs singly ${ }^{13} \mathrm{CO}$ labeled at A6 or A14. To our knowledge, these data are the first measurements of distances between HIV fusion peptide nuclei and lipid $\mathrm{P}$ and qualitative models of membrane location of oligomeric $\beta$ strand HFP are presented which are consistent with the experimental data. Observation of intimate contact between $\beta$ strand HFP and membranes provides rationale for further investigation of the relationship between structure and fusion activity for this conformation.
\end{abstract}

\section{Keywords}

HIV; fusion peptide; membrane; carbonyl; phosphorus; REDOR; NMR

\begin{abstract}
The infection of enveloped viruses such as human immunodeficiency virus (HIV) begins with fusion between the viral and host cell membranes (1-4). Fusion may be catalyzed by fusion proteins and several models of fusion protein catalysis have been proposed (2,5-7). For HIV, fusion is catalyzed by a "gp160" glycoprotein complex which is incorporated in the virus membrane and is composed of two non-covalently associated subunits "gp120" and "gp41". The gp120 subunit lies outside the virus and binds to receptors in the target cell membrane and the gp41 subunit contains a region inside HIV as well as a single-pass transmembrane domain
\end{abstract}

\footnotetext{
*To whom correspondence should be addressed. Telephone: 517-355-9715. Fax: 517-353-1793. Email: weliky@ chemistry.msu.edu.

${ }^{\dagger}$ This work was supported by NIH award AI47153 to D. P. W.
} 
$(8,9)$. The $~ 170$ - residue ectodomain of gp41 lies outside HIV and is subdivided into a more C-terminal "soluble ectodomain" and a 20-residue N-terminal fusion peptide (HFP) which is apolar and fairly conserved. The HFP is believed to interact with the target cell membrane after gp120 binds to cellular receptors and fusion is greatly disrupted by mutation or deletion of the HFP (10-13).

Peptides with the HFP sequence catalyze vesicle fusion and there are good correlations between the mutation/fusion activity relationships of HFP-induced vesicle fusion and HIV/target cell fusion (14-17). Studies of membrane-associated HFP should therefore provide useful information about some aspects of biological fusion. Both the conformation and membrane location of the HFP have been hypothesized to be significant structural factors for fusion catalysis by the HFP $(16,18)$. The conformation of the HFP has been investigated in detergent micelles and membranes using a variety of biophysical techniques. For HFP associated with negatively charged sodium dodecyl sulfate micelles, one liquid-state nuclear magnetic resonance (NMR) study showed that there was uninterrupted $\alpha$ helical structure from I4 to M19 while another study showed a helix from I4 to A14 followed by a $\beta$ turn $(19,20)$. For HFP associated with neutral dodecylphosphocholine micelles, helical structure was detected from I4 to L12 (21, C. M. Gabrys and D. P. Weliky, unpublished data). There is not yet a consensus for the micelle location of HFP and there are distinct models based on experiment and simulation of either predominant micelle surface location or micelle traversal by HFP (1923). In one NMR study, residues I4 to A15 were found to be fully shielded from solvent and residues G3 and G16 were at the micelle/solvent interface (20).

The conformation of membrane-associated HFP has been investigated with different lipid components and different peptide:lipid ratios. A greater fraction of HFPs adopted helical structure at low peptide:lipid while non-helical structure became more favored at higher ratios (24). Helical structure was also promoted by negatively charged lipids while a higher fraction of $\beta$ strand structure was adopted with neutral lipids or with bound $\mathrm{Ca}^{2+}(16,24-26)$. Solidstate NMR provided residue-specific conformational information of HFP associated with membranes whose lipid headgroup and cholesterol composition was comparable to that of host cells of the virus. A $\beta$ strand conformation was observed for residues A1 to G16 while A21 appeared to be unstructured $(27,28)$. Formation of $\beta$ strand oligomers or aggregates was supported by detection of short distances between labeled ${ }^{13} \mathrm{CO}$ on one HFP and labeled ${ }^{15} \mathrm{~N}$ on an adjacent HFP (29). Oligomerization/aggregation has also been detected by other biophysical methods $(15,30)$. There is evidence that at least the lipid mixing step of membrane fusion can occur with the HFP in either helical or $\beta$ strand conformation although there is some controversy in the literature about this conclusion (14,16,18,31-35).

HFP location in membranes has been primarily probed using a HFP-F8W mutant and by variation of the tryptophan fluorescence of this mutant with changes in environment $(36,37)$. Key results have included: (1) fluorescence was higher for membrane-associated HFP-F8W than for HFP-F8W in buffered saline solution; (2) greater fluorescence quenching by acrylamide was observed for a soluble tryptophan analog than for membrane-associated HFPF8W; and (3) similar fluorescence quenching of membrane-associated HFP-F8W was observed in samples containing either 1-palmitoyl-2-stearoyl-phosphocholine brominated at the 6,7 carbons of the stearoyl chain or the corresponding lipid brominated at the 11,12 carbons of the chain. The first two results indicated that solvent exposure of the HFP-F8W tryptophan is reduced with membrane association and the third result indicated that the membrane location of the tryptophan indole group is centered near the carbon 9 position of the brominated lipid stearoyl chain; i.e. $\sim 8.5 \AA$ from the bilayer center and $\sim 10 \AA$ from the lipid phosphorus. Infrared (IR) and solid-state NMR spectra of membrane-associated HFP suggested that the HFP-F8W had predominant $\beta$ strand conformation under the conditions of the fluorescence experiments $(16,27,36,37)$. 
In a different set of experiments, electron spin resonance spectra showed that chromium oxalate in the aqueous phase quenched the signal of membrane-associated HFP which was spin-labeled at M19 but did not quench HFP spin-labeled at A1 (30). These data indicated a M19 location close to the aqueous interface of the membrane and an A1 location away from this interface.

Models for HFP location in membranes have also been developed from simulations of a single HFP molecule in membranes and have shown either partial insertion or traversal of the membrane. The HFP always adopted predominant $\alpha$ helical conformation and in one simulation was generally near the membrane surface with the F8 backbone and sidechain nuclei respectively $4 \AA$ and $6 \AA$ deeper than the phosphorus longitude (38). For a different simulation, HFP traversed the membrane and the backbone and sidechain F8 nuclei were at the bilayer center, i.e. $\sim 19 \AA$ from the phosphorus longitude (39).

This paper includes solid-state NMR measurements of distances between ${ }^{13} \mathrm{C}$ labeled carbonyl $\left({ }^{13} \mathrm{CO}\right)$ nuclei in $\mathrm{HFP}$ and lipid ${ }^{31} \mathrm{P}$ nuclei. These studies provide information about the location of specific HFP residues relative to the phosphorus headgroups and are complementary to other solid-state NMR methods to probe membrane location of peptides and proteins (40-50). The ${ }^{13} \mathrm{CO}_{-}{ }^{31} \mathrm{P}$ distance approach has previously been used to probe the locations of antimicrobial peptides, antibiotics, and sterols in membranes (51-53). Measurements were made both on HFP associated with membranes containing only phospholipids and on HFP associated with membranes which contained both phospholipids and cholesterol. The potential significance of cholesterol-containing membranes is suggested both by the cholesterol:phospholipid mol ratios of $\sim 0.5$ and 0.8 for HIV host cell and HIV membranes, respectively, and by the observation that $\beta$ strand conformation of HFP is promoted by membrane cholesterol $(27,35,54-57)$.

The ${ }^{13} \mathrm{CO}-{ }^{31} \mathrm{P}$ distances $(r)$ were probed with the rotational-echo double resonance (REDOR) technique which is a solid-state NMR method to measure magnitudes of dipolar couplings (d) between spin $1 / 2$ heteronuclei such as ${ }^{13} \mathrm{C}$ and ${ }^{31} \mathrm{P}(58)$. For a ${ }^{13} \mathrm{CO}-{ }^{31} \mathrm{P}$ spin pair, $r=23.05 /$ $d^{1 / 3}$ where $r$ and $d$ are in units of $\AA$ and Hz, respectively. The upper limit of REDOR detection of $r$ is $\sim 10 \AA(d \geq 10 \mathrm{~Hz})(35)$.

\section{MATERIALS AND METHODS}

\section{Materials}

Resins and 9-fluorenylmethoxycarbonyl (FMOC) amino acids were obtained from Peptides International (Louisville, KY). ${ }^{13} \mathrm{CO}$-isotopically labeled amino acids were obtained from Cambridge Isotope Laboratories (Andover, MA). The lipids 1,2-di-Otetradecyl-sn-glycero-3phosphocholine (DTPC), 1,2-di-O-tetradecyl-sn-glycero-3-[phospho-rac-(1-glycerol)] (DTPG), and $\left[1-{ }^{13} \mathrm{C}\right]-1,2$-dipalmitoyl-sn-glycero-3-phosphocholine (DPPC- $\left.{ }^{13} \mathrm{C}\right)$ were obtained from Avanti Polar Lipids (Alabaster, AL). The $5 \mathrm{mM}$ HEPES buffer at $\mathrm{pH} 7$ contained $0.01 \%(\mathrm{w} / \mathrm{v}) \mathrm{NaN}_{3}$ preservative.

\section{Peptides}

All peptides contained the sequence AVGIGALFLGFLGAAGSTMGARS which is the $23 \mathrm{~N}$ terminal residues of HIV-1 gp41, $\mathrm{LAV}_{1 \mathrm{a}}$ strain. A set of peptides were synthesized to probe peptide/lipid headgroup distances between G5 and G16. "HFP1- ${ }^{8}$ FLG" had the sequence AVGIGALFLGFLGAAGSTMGARS- $\mathrm{NH}_{2}$ and was ${ }^{13} \mathrm{CO}$ labeled at $\mathrm{F} 8, \mathrm{~L} 9$, and $\mathrm{G} 10$. "HFP2- ${ }^{5}$ GAL", "HFP2- ${ }^{11}$ FLG", and "HFP2- ${ }^{14}$ AAG" had the sequence AVGIGALFLGFLGAAGSTMGARSKKK- $\mathrm{NH}_{2}$ and were ${ }^{13} \mathrm{CO}$ labeled at G5, A6, L7; F11, L12, G13; or A14, A15, G16, respectively. The three non-native lysines increased aqueous solubility and resulted in monomeric peptide in the buffer solution prior to membrane binding 
(59). "HFP3- ${ }^{8}$ FLG" had sequence AVGIGALFLGFLGAAGSTMGARSKKKA $\beta$ and was ${ }^{13} \mathrm{CO}$ labeled at F8, L9, and G10 and "HFP4", "HFP4- ${ }^{6} \mathrm{~A}$ ", and "HFP4- ${ }^{14} \mathrm{~A}$ " had sequence AVGIGALFLGFLGAAGSTMGARSWKKKKKKA $\beta$ and were unlabeled or ${ }^{13} \mathrm{CO}$ labeled at A6 or A14, respectively. The $\beta$-alanine resin used for the HFP3 and HFP4 syntheses had a low substitution which helped to increase yield. All peptides were synthesized using an ABI 431 A peptide synthesizer (Foster City, CA) and FMOC chemistry. Peptides were cleaved from the resin for 2-3 hours using either a mixture of trifluoroacetic acid

(TFA):water:phenol:thioanisole:ethanedithiol:water in a 33:2:2:2:1 volume ratio or a mixture of TFA:thioanisole:ethanedithiol:anisole in a 90:5:3:2 volume ratio. TFA was removed from the cleavage filtrate with nitrogen gas and peptides were precipitated with cold t-butyl methyl ether. Peptides were purified by reversed-phased high performance liquid chromatography using a semi-preparative $\mathrm{C}_{18}$ column and a water-acetonitrile gradient containing $0.1 \%$ TFA. Mass spectroscopy was used for peptide identification.

\section{NMR sample preparation}

Samples were made with the ether-linked lipids DTPC and DTPG because these are commercially available lipids which do not contain carbonyl groups. The liquid-crystalline to gel phase transition temperatures of DTPC and DTPG are $\sim 28 \mathrm{C}$ and are close to the $\sim 23 \mathrm{C}$ phase transition temperatures of the corollary ester-linked lipids 1,2-dimyristoyl-sn-glycero-3phosphocholine and 1,2-dimyristoyl-sn-glycero-3-[phospho-rac-(1-glycerol)] (60). If NMR samples had been made with the more typical ester-linked lipids, there would be large natural abundance lipid ${ }^{13} \mathrm{CO}$ signals which would overlap with the peptide ${ }^{13} \mathrm{CO}$ signals (35). For such samples, analysis of the peptide ${ }^{13} \mathrm{CO}$-lipid ${ }^{31} \mathrm{P}$ distances would then be complicated by the close proximity of the lipid ${ }^{13} \mathrm{CO}$ to lipid ${ }^{31} \mathrm{P}$. All samples contained a 4:1 DTPC:DTPG mol ratio which reflected the approximate ratio of neutral:negatively charged headgroups in membranes of host cells of HIV $(54,57)$. For each triply ${ }^{13} \mathrm{CO}$-labeled HFP, a sample was made with DTPC:DTPG $=4: 1 \equiv$ "PC:PG" and a sample was made with DTPC:DTPG:cholesterol = 8:2:5 $\equiv$ "PC:PG:CHOL". The latter total lipid:cholesterol mol ratio reflected the ratio observed in membranes of host cells of HIV and the former PC:PG composition without cholesterol was similar to membrane compositions used in previous structural studies of fusion peptides (54, 57,61-63). The samples containing singly ${ }^{13} \mathrm{CO}$-labeled HFP were prepared with PC:PG:CHOL.

Each sample preparation began with dissolution in chloroform of $20 \mu \mathrm{mol}$ total PC:PG or 30 $\mu$ mol total PC:PG:CHOL. The chloroform was removed under a stream of nitrogen followed by overnight vacuum pumping. The lipid film was suspended in $2 \mathrm{~mL}$ buffer and homogenized with ten freeze-thaw cycles. Large unilamellar vesicles were formed by extrusion through a $100 \mathrm{~nm}$ diameter polycarbonate filter (Avestin, Ottawa, ON). HFP $(0.8 \mu$ mol by weight) was dissolved in $2 \mathrm{~mL}$ buffer and the HFP and vesicle solutions were then gently vortexed together. The mixture was refrigerated overnight and ultracentrifuged at $\sim 150000 \mathrm{~g}$ for five hours. The membrane pellet with associated bound HFP was transferred to a $4 \mathrm{~mm}$ diameter magic angle spinning (MAS) NMR rotor. The majority of the HFP binds to membranes under these conditions and the membranes remain bilayers for HFP:lipid $0.04(27,56,59,64)$.

A sample was also prepared for calibration of the NMR experiments and contained HFP4 (0.8 $\mu \mathrm{mol})$ and DPPC- ${ }^{13} \mathrm{C}(20 \mu \mathrm{mol})$. The ${ }^{13} \mathrm{CO}$ signal of this sample was dominated by DPPC- ${ }^{13} \mathrm{C}$.

\section{Solid-state NMR}

Experiments were done on a 9.4 T solid-state NMR spectrometer (Varian Infinity Plus, Palo Alto, CA) equipped with a triple resonance MAS probe. The detection channel was tuned to ${ }^{13} \mathrm{C}$ at $100.8 \mathrm{MHz}$, the decoupling channel was tuned to ${ }^{1} \mathrm{H}$ at $400.8 \mathrm{MHz}$, and the third 
channel was tuned to ${ }^{31} \mathrm{P}$ at $162.2 \mathrm{MHz} \cdot{ }^{13} \mathrm{C}$ shifts were externally referenced to the methylene resonance of adamantane at $40.5 \mathrm{ppm},{ }^{31} \mathrm{P}$ shifts were referenced to $85 \% \mathrm{H}_{3} \mathrm{PO}_{4}$ at $0 \mathrm{ppm}$, and the ${ }^{13} \mathrm{C}$ and ${ }^{31} \mathrm{P}$ transmitter chemical shifts were 156 and $-16 \mathrm{ppm}$, respectively. The ${ }^{13} \mathrm{C}$ referencing allowed direct comparison with ${ }^{13} \mathrm{C}$ shift databases derived from liquid-state NMR assignments of proteins $(65,66)$. These databases are appropriate for solid-state NMR data as evidenced by similar ${ }^{13} \mathrm{C}$ shifts observed for the same protein in either aqueous solution or the microcrystalline state (67-69). experiments were done at $-50 \mathrm{C}$ to enhance ${ }^{13} \mathrm{C}$ signal and to prevent motional averaging of the ${ }^{13} \mathrm{C}-{ }^{31} \mathrm{P}$ dipolar coupling which was the parameter used to assess HFP location in membranes. The ${ }^{13} \mathrm{C}$ shifts and presumably the HFP conformation were comparable at $-50 \mathrm{C}$ and ambient temperature (70). At $-50 \mathrm{C}$, the lipids were likely in the gel phase for the PC:PG samples and in the liquid-ordered phase for the PC:PG:CHOL samples $(60,71)$. Analyses of slow-spinning spectra yielded a ${ }^{13} \mathrm{CO}$ chemical shift anisotropy range of $\sim 90$ to $240 \mathrm{ppm}$ and a ${ }^{31} \mathrm{P}$ chemical shift anisotropy range of $\sim-75$ to $100 \mathrm{ppm}(72)$. The REDOR experiment contained in sequence: (1) a $50 \mathrm{kHz}{ }^{1} \mathrm{H} \pi / 2$ pulse; (2) 1 ms crosspolarization with $52 \mathrm{kHz}{ }^{1} \mathrm{H}$ field and $58-69 \mathrm{kHz}$ ramped ${ }^{13} \mathrm{C}$ field; (3) a dephasing period of duration $\tau$ which contained $\sim 50 \mathrm{kHz}{ }^{13} \mathrm{C} \pi$ and in some cases $\sim 60 \mathrm{kHz}{ }^{31} \mathrm{P} \pi$ pulses with XY-8 phase cycling on each channel; and (4) ${ }^{13} \mathrm{C}$ detection with a four scan phase cycle $(29,35,73-$ 75). Two-pulse phase modulation ${ }^{1} \mathrm{H}$ decoupling of $\sim 100 \mathrm{kHz}$ was applied during the dephasing and detection periods, the recycle delay was $1 \mathrm{~s}$, and the MAS frequency was $8000 \pm 2 \mathrm{~Hz}$ (76).

For each sample and each $\tau$, two spectra were acquired. The dephasing period during the " $S_{1}$ " acquisition contained a ${ }^{13} \mathrm{C} \pi$ pulse at the end of each rotor cycle except for the last cycle and a ${ }^{31} \mathrm{P} \pi$ pulse in the middle of each cycle. The ${ }^{31} \mathrm{P}$ pulses were absent during the " $\mathrm{S}_{0}$ " acquisition. MAS averaged the ${ }^{13} \mathrm{C}_{-}{ }^{31} \mathrm{P}$ dipolar coupling to zero over each rotor cycle of the dephasing period of the $S_{0}$ acquisition, while incorporation of two $\pi$ pulses per rotor cycle during the $S_{1}$ acquisition resulted in a non-zero average value of the dipolar coupling and concomitant reduction in signals of ${ }^{13} \mathrm{C}$ nuclei close to ${ }^{31} \mathrm{P}$. Determination of $d$ was based on the difference in ${ }^{13} \mathrm{C}$ signal intensity of the two spectra.

The ${ }^{1} \mathrm{H}$ and ${ }^{13} \mathrm{C}$ rf fields were initially calibrated with adamantane and the ${ }^{13} \mathrm{C}$ crosspolarization field was then adjusted to give the maximum ${ }^{13} \mathrm{CO}$ signal of the sample containing unlabeled HFP4 and DPPC- ${ }^{13} \mathrm{C}$. The ${ }^{31} \mathrm{P} \pi$ pulse length was set by minimization of the $S_{1}$ signal in this sample for $\tau=8 \mathrm{~ms}$ and the ${ }^{1} \mathrm{H}$ TPPM pulse length was set to give the maximum $S_{0}$ signal.

\section{REDOR data analysis}

All spectra were processed with Gaussian line broadening and with baseline correction. For each sample and each value of $\tau$, spectra were integrated over a defined chemical shift range and the integrals of the $S_{0}$ and $S_{1}$ spectra were denoted as " $S_{0}$ " and " $S_{1}$ " and were used to calculate a normalized experimental dephasing parameter $\left(\Delta S / S_{0}\right)^{\exp }=1-\left(S_{1} / S_{0}\right)$. Uncertainties in $\left(\Delta S / S_{0}\right)^{\exp }$ were calculated:

$$
\sigma^{\exp }=\frac{\sqrt{\left(S_{0}^{2} \times{\sigma_{S_{1}}}^{2}\right)+\left(S_{0}^{2} \times{\sigma_{s_{0}}}^{2}\right)}}{S_{0}{ }^{2}}
$$

where $\sigma S_{0}$ and $\sigma S_{1}$ were the experimental root-mean-squared-deviations of integrated intensities in regions of the spectra without signal (77). relative to the other labeled HFP samples, the HFP2- ${ }^{14}$ AAG and HFP4- ${ }^{14}$ A samples had significantly larger values of $(\Delta S /$ $\left.S_{0}\right)^{e x p}$ and data from these samples were used to determine an approximate distance between 
the ${ }^{31} \mathrm{Ps}$ and the labeled ${ }^{13} \mathrm{COs}$. The distance determination was done with $\left(\Delta S / S_{0}\right){ }^{l a b}$ calculated to remove the natural abundance $(n a)$ contribution from $\left(\Delta S / S_{0}\right)^{\exp \text { : }}$

$$
\left(\frac{\Delta S}{S_{0}}\right)^{\mathrm{lab}}=\left[\left(1+\frac{S_{0}^{n a}}{S_{0}^{\mathrm{lab}}}\right) \times\left(\frac{\Delta S}{S_{0}}\right)^{\mathrm{exp}}\right]-\left[\left(\frac{S_{0}^{n a}}{S_{0}^{\mathrm{lab}}}\right) \times\left(\frac{\Delta S}{S_{0}}\right)^{n a}\right]
$$

The values of $\left(S_{0}{ }^{n a} / S_{0}{ }^{l a b}\right)$ were 0.084 and 0.32 for the HFP2- ${ }^{14}$ AAG and HFP4- ${ }^{14}$ A samples, respectively. The values of $\left(\Delta S / S_{0}\right)^{n a}$ were calculated as the average of $\left(\Delta S / S_{0}\right)^{\text {exp }}$ for the HFP2- ${ }^{5} \mathrm{GAL}, \mathrm{HFP} 3-{ }^{8} \mathrm{FLG}$, and HFP2- ${ }^{11}$ FLG samples and for $\tau=2,8,16$, and $24 \mathrm{~ms}$ were 0.000, 0.029, 0.094, and 0.134 for the PC:PG samples and 0.026, 0.028, 0.083, and 0.092 for the PC:PG:CHOL samples. The $\sigma^{l a b}$ were calculated with $\sigma^{l a b}=\left(1+S_{0}{ }^{n a} / S_{0}{ }^{l a b}\right) \times \sigma^{\exp }$ which neglected the contribution from the far-right term in Eq. 2. Discussion of this approximation and derivation of Eq. 2 are given in the Supporting Information.

Simulations of the experimental data were based on a single ${ }^{13} \mathrm{CO}-{ }^{31} \mathrm{P}$ spin pair model:

$$
\left(\frac{\Delta S}{S_{0}}\right)^{\operatorname{sim}}=1-\left[J_{0}(\sqrt{2} \lambda)\right]^{2}+\left\{2 \times \sum_{k=1}^{5} \frac{\left[J_{k}(\sqrt{2} \lambda)\right]^{2}}{16 k^{2}-1}\right\}
$$

with $\lambda=d \times \tau$ and $J_{k}$ as the $k^{t h}$ order Bessel function of the first kind (78). The samples contained multiple ${ }^{13} \mathrm{CO}-{ }^{31} \mathrm{P}$ distances and couplings and these are approximated as a single $r$ and a single $d$ in Eq. $3(29,51,79)$.

For the HFP4/DPPC- ${ }^{13} \mathrm{C}$ sample, $\chi^{2}(d)$ were calculated for an array of values of $d$ :

$$
\chi^{2}(d)=\sum_{i=1}^{T} \frac{\left[\left(\frac{\Delta S}{S_{0}}\right)_{i}^{\exp }-\left(\frac{\Delta S}{S_{0}}(d)\right)_{i}^{\operatorname{sim}}\right]^{2}}{\left(\sigma_{i}^{\exp }\right)^{2}}
$$

where $T$ was the number of experimental $\tau$ values. The best-fit $d$ corresponded to minimum $\chi^{2}(d)$.

At larger $\tau$, the $\left(\Delta S / S_{0}\right){ }^{l a b}$ for the HFP2- ${ }^{14}$ AAG and HFP4- ${ }^{14}$ A samples reached plateau values which were significantly smaller than 1 while the $\left(\Delta S / S_{0}\right)^{\operatorname{sim}}$ had plateau values of $\sim 1$. This inconsistency was resolved using a model of two populations of membrane-associated HFPs. The " $f$ " fraction represented ${ }^{13} \mathrm{COs}$ close to the lipid ${ }^{31} \mathrm{Ps}$ with corresponding $d \neq 0$ while the " $1-f$ " fraction represented ${ }^{13} \mathrm{CO}$ far from the lipid ${ }^{31} \mathrm{Ps}$ with corresponding $d=0$. Fitting was done with an array of values of $d$ and $f$ :

$$
\chi^{2}(d)=\sum_{i=1}^{T} \frac{\left[\left(\frac{\Delta S}{S_{0}}\right)_{i}^{\mathrm{lab}}-\left\{f \times\left(\frac{\Delta S}{S_{0}}(d)\right)_{i}^{\mathrm{sim}}\right\}\right]^{2}}{\left(\sigma_{i}^{\mathrm{lab}}\right)^{2}}
$$

The uncertainty of $d$ was calculated with the $\chi^{2}=\chi^{2}$ min +1 criterion (77). 


\section{RESULTS}

\section{Overall strategy}

Our long-term goal is a detailed structure of the membrane location of the HFP in helical and $\beta$ strand conformations. Prior to beginning this study, there was relatively little information about the membrane location of HFP, particularly for the $\beta$ strand conformation. It was likely that a large number of ${ }^{13} \mathrm{CO}$ sites had ${ }^{13} \mathrm{CO}-{ }^{31} \mathrm{P}$ distances beyond the REDOR detection limit. In addition, $\mathrm{HFP}{ }^{13} \mathrm{C}$ linewidths are fairly broad which leads to overlap of ${ }^{13} \mathrm{CO}$ resonances from different residues and the need for specific ${ }^{13} \mathrm{CO}$ labeling. In an effort to reduce the numbers of specifically labeled peptides needed to develop a membrane location model, samples were first made with four peptides each of which had ${ }^{13} \mathrm{CO}$ labels at three sequential residues between G5 and G16. The G5-G16 region was therefore rapidly scanned for ${ }^{13} \mathrm{CO}-{ }^{31} \mathrm{P}$ proximity. Although the $\left(\Delta S / S_{0}\right){ }^{\exp }$ data for each of the samples had contributions from three distinct ${ }^{13} \mathrm{CO}$ sites, the individual $\left(\Delta S / S_{0}\right)$ would only be appreciably greater than zero for ${ }^{13} \mathrm{CO}-{ }^{31} \mathrm{P}$ distances $\leq 8 \AA$. The regions of HFP close to ${ }^{31} \mathrm{P}$ would be defined from the REDOR data on the triply labeled samples and these regions would then provide a basis for choosing sites for single ${ }^{13} \mathrm{CO}$ labeled peptides. ${ }^{13} \mathrm{CO}-{ }^{31} \mathrm{P}$ distances are more straightforwardly derived from $\left(\Delta S / S_{0}\right)$ of singly labeled HFPs and REDOR data for two such HFPs are presented to refine the basic HFP membrane location model developed from the triply labeled HFP data.

\section{REDOR calibration experiments}

As an initial control experiment, ${ }^{13} \mathrm{CO}-{ }^{31} \mathrm{P}$ REDOR spectra were obtained for HFP2- ${ }^{11} \mathrm{FLG}$ lyophilized from water and resulted in $\left(\Delta S / S_{0}\right)^{\exp } \sim 0$ for values of $\tau$ between 1 and $19 \mathrm{~ms}$, Fig. $1 \mathrm{a}-\mathrm{c}$. Non-zero values of $\left(\Delta S / S_{0}\right)^{e x p}$ for ${ }^{13} \mathrm{COs}$ in membrane-associated HFP samples can therefore be definitively ascribed to ${ }^{13} \mathrm{CO}-{ }^{31} \mathrm{P}$ proximity. As displayed in Fig. 1d-g, REDOR spectra were also obtained for the HFP4/DPPC- ${ }^{13} \mathrm{C}$ sample. Because HFP4 is unlabeled and DPPC- $-{ }^{13} \mathrm{C}$ is labeled, the signals were primarily due to the DPPC ${ }^{13} \mathrm{CO}$ and have non-zero $\left(\Delta S / S_{0}\right)^{e x p}$ because of the proximity of the headgroup ${ }^{31} \mathrm{P}$. Fig. 2 displays $\left(\Delta S / S_{0}\right)^{\exp }$ and bestfit $\left(\Delta S / S_{0}\right)^{s i m}$ for this sample and yielded $d=68 \mathrm{~Hz}$ and $r=5.6 \AA$. The best-fit NMR value of $r$ is comparable to the 5-6 $\AA$ values of $r$ observed in the crystal structures of the related lipids, 1,2-dimyristoyl-sn-glycero-3-phosphocholine and 1,2-dipalmitoyl-sn-glycero-[phospho-rac(1-glycerol)] (which had both been dehydrated) and in molecular dynamics simulations of gelphase DPPC (80-82). The differences between $\left(\Delta S / S_{0}\right)^{\exp }$ and $\left(\Delta S / S_{0}\right)^{\text {sim }}$ are likely due to: (1) contributions to $\left(\Delta S / S_{0}\right)^{\text {exp }}$ from intra- and intermolecular ${ }^{31} \mathrm{P}$ with comparable values of $r$ which contrasts with the single ${ }^{13} \mathrm{CO}-{ }^{31} \mathrm{P}$ spin pair model used to calculate $\left(\Delta S / S_{0}\right)^{\operatorname{sim}}$; (2) two structurally distinct ${ }^{13} \mathrm{COs}$ in each headgroup with different intra- and intermolecular $r$ values; and (3) structural disorder within the headgroups (79). Overall, the DPPC- ${ }^{13} \mathrm{C}$ fitting yielded good agreement between the NMR $r$ value and the expected range of $r$ values in the lipid.

For the HFP4/DPPC- ${ }^{13} \mathrm{C}$ sample, experiments were also done with a "one-channel" version of the REDOR sequence for which the $S_{1}$ acquisitions contained a single ${ }^{13} \mathrm{C} \pi$ pulse at the center of the dephasing period and ${ }^{31} \mathrm{P} \pi$ pulses in the middle and end of each rotor cycle except for the center and end of the dephasing period. The $S_{0}$ acquisition did not have ${ }^{31} \mathrm{P} \pi$ pulses. relative to the "two-channel" version of REDOR described in Materials and Methods, onechannel REDOR has a reduced number of ${ }^{13} \mathrm{C} \pi$ pulses which could result in reduced ${ }^{13} \mathrm{C}-{ }^{13} \mathrm{C}$ dipolar coupling and larger overall signals $(83,84)$. In fact, the experimental $S_{0}$ intensities were comparable for the two versions of REDOR while $\left(\Delta S / S_{0}\right)^{\exp }$ for onechannel REDOR was $\sim 2 / 3$ that of two-channel REDOR (29). All subsequent experiments were done with two-channel REDOR. 


\section{Triply labeled HFP}

Local peptide conformation was examined by analysis of the ${ }^{13} \mathrm{CO}$ chemical shift distributions in $S_{0}$ spectra of HFPs obtained with $\tau=2 \mathrm{~ms}$, cf. Fig. 3. The data supported the following models: (1) the major fraction of peptides in PC:PG and PC:PG:CHOL adopted a $\beta$ strand conformation from G5 to G16; and (2) there is a minor fraction of peptides in PC:PG with helical conformation. The detailed experimental support for the models is based on the known correlation between larger ${ }^{13} \mathrm{CO}$ chemical shifts and local helical conformation and smaller ${ }^{13} \mathrm{CO}$ chemical shifts and local $\beta$ strand conformation. For example, average database values in ppm units of ${ }^{13} \mathrm{CO}$ chemical shifts of helix (strand) conformations are: Gly, 175.5 (172.6); Ala, 179.4 (176.1); Leu, 178.5 (175.7); and Phe, 177.1 (174.2) (66). For the HFP2- ${ }^{5}$ GAL, HFP3- ${ }^{8}$ FLG, HFP2- ${ }^{11}$ FLG, and HFP2- ${ }^{14}$ AAG samples, the peak chemical shifts were $\sim 175,174,175$, and $176 \mathrm{ppm}$, respectively, and correlated with $\beta$ strand conformation for the Ala, Leu, and Phe residues. For the HFP3- ${ }^{8}$ FLG and HFP2- ${ }^{14}$ AAG samples associated with PC:PG, there were shoulders at $\sim 178$ and 179 ppm, respectively, which correlated with helical conformation of Ala, Leu, and Phe residues. These results were consistent with previous studies of the conformation of membrane-associated HFP with peptide:lipid $\sim 0.04$ and with previous observations of greater preference for $\beta$ strand conformation in cholesterol-containing membranes $(27,28,35,55,56,59,70)$.

Fig. 4 displays the $\tau=16$ and 24 ms REDOR spectra of triply-labeled membrane-associated HFP samples and Fig. 5a,b displays comparative plots of $\left(\Delta S / S_{0}\right)^{\exp }$ for the different samples. The data demonstrated that samples containing HFP2- ${ }^{14}$ AAG have qualitatively larger $(\Delta S /$ $\left.S_{0}\right)^{\exp }$ than do samples containing HFP labeled at other residues. Using the conformational results from Fig. 3, it appears: (1) a significant fraction of $\beta$ strand HFP are in close contact with membranes; and (2) the ${ }^{14} \mathrm{AAG}$ (A14 to G16) region is closer to the lipid ${ }^{31} \mathrm{P}$ than is the ${ }^{5}$ GALFLGFLG (G5 to G13) region. Fig. $5 \mathrm{c}$,d displays plots of $\left(\Delta S / S_{0}\right)^{l a b}$ and best-fit $\left(\Delta S / S_{0}\right)^{s i m}$ for HFP2- ${ }^{14}$ AAG in PC:PG and PC:PG:CHOL. The best-fit $r$ was $\sim 5.2 \AA$ in both membrane compositions and the best-fit $f$ in PC:PG and PC:PG:CHOL were 0.45 and 0.32 , respectively. It was not possible to fit the HFP2- ${ }^{14} \mathrm{AAG}$ data well without inclusion of the $f$ parameter. Although the $\left(\Delta S / S_{0}\right)^{l a b}$ had contributions from three ${ }^{13} \mathrm{CO}$ sites which would each have a distinct $r$, the number of data points and signal-to-noise dictated fitting to a single $r$ value. The best-fit $r$ should therefore be considered as both approximate and as likely representing the population of ${ }^{13} \mathrm{CO}$ sites with greatest $d$ and smallest $r$. Fitting was not done for data from the other samples because of the small $\left(\Delta S / S_{0}\right)^{\exp }$ and because the $\left(\Delta S / S_{0}\right)^{\exp }$ do not always reach asymptotic values at large $\tau$.

Spectra were also obtained for samples made with HFP1 ${ }^{8} \mathrm{FLG}$, the peptide which did not contain C-terminal lysines. For $\tau=2,8,16$, and $24 \mathrm{~ms},\left(\Delta S / S_{0}\right)^{\exp }=-0.02,0.06,0.11$, and 0.08 for the HFP1- ${ }^{8} \mathrm{FLG} / \mathrm{PC}: \mathrm{PG}$ sample and $0.01,0.03,0.01$, and -0.01 for the HFP1- ${ }^{8} \mathrm{FLG} /$ PC:PG:CHOL sample. These values correlated with the $\left(\Delta S / S_{0}\right)^{\exp }$ of the respective HFP3- ${ }^{8}$ FLG/PC:PG and HFP3- ${ }^{8}$ FLG/PC:PG:CHOL samples (circles in Fig. 5) and suggested that the additional C-terminal lysines of HFP2 and HFP3 do not greatly affect the REDOR results.

\section{Singly labeled HFP}

The triply labeled HFP results motivated experiments on singly labeled HFP4- ${ }^{6} \mathrm{~A}$ and HFP4- ${ }^{14} \mathrm{~A}$ associated with PC:PG:CHOL. As discussed in the Overall strategy subsection, analysis of singly labeled HFP data should result in more quantitative assessment of $r$. In addition, we were interested in studying HFP in a single conformation and the Fig. 3 data suggested that this was best achieved with PC:PG:CHOL and the resulting predominant $\beta$ strand conformation. Finally, the Fig. 5 data suggested that $\left(\Delta S / S_{0}\right)^{l a b}$ would be about zero for a HFP4- ${ }^{6} \mathrm{~A} / \mathrm{PC}: \mathrm{PG}: \mathrm{CHOL}$ sample and could be nonzero for a HFP4- ${ }^{14} \mathrm{~A} / \mathrm{PC}: \mathrm{PG}: \mathrm{CHOL}$ 
sample. REDOR data from these two sites could therefore further test the qualitative membrane location model derived from the triply labeled HFP results.

Fig. 6a,b displays the respective $S_{0}$ spectra at $\tau=8 \mathrm{~ms}$ for HFP4- ${ }^{6} \mathrm{~A}$ and HFP4- ${ }^{14} \mathrm{~A}$ associated with PC:PG:CHOL. Single peaks were observed with peak shifts of $\sim 175 \mathrm{ppm}$ which correlated with $\beta$ strand conformation at these residues. The spectrum of HFP4- ${ }^{14} \mathrm{~A}$ is similar to a difference spectrum representing the Ala- $14{ }^{13} \mathrm{CO}$ signal for HFP (with no lysines) associated with an ester-linked lipid and cholesterol composition close to that of host cells of HIV (27). Fig. 6c,d displays the $\tau=16$ and $24 \mathrm{~ms}$ REDOR spectra of the singly labeled HFP4 samples and Fig. 7 shows $\left(\Delta S / S_{0}\right)^{e x p}$ plots and data fitting for the HFP4- ${ }^{14} \mathrm{~A}$ data. At large $\tau,(\Delta S /$ $\left.S_{0}\right)^{\text {exp } \approx 0}$ for the HFP4- ${ }^{6}$ A sample and $\left(\Delta S / S_{0}\right)^{\text {exp }}$ were significantly greater than zero for the HFP4- ${ }^{14} \mathrm{~A}$ sample. Fitting of the HFP4- ${ }^{14} \mathrm{~A}$ data with a single ${ }^{13} \mathrm{CO}-{ }^{31} \mathrm{P}$ spin pair model yielded best-fit $r$ and $f$ of $5.1 \AA$ and 0.29 , respectively. Thus, there was general consistency between the REDOR data of the HFP4- ${ }^{6} \mathrm{~A} / \mathrm{PC}: \mathrm{PG}: \mathrm{CHOL}$ and the HFP2- ${ }^{5} \mathrm{GAL} / \mathrm{PC}: \mathrm{PG}: \mathrm{CHOL}$ samples and the REDOR data and fitting of the HFP4- ${ }^{14} \mathrm{~A} / \mathrm{PC}: \mathrm{PG}: \mathrm{CHOL}$ and the HFP2- ${ }^{14} \mathrm{AAG} /$ PC:PG:CHOL samples.

\section{DISCUSSION}

\section{Insertion models}

The position of the HFP in the membrane has been postulated to be a significant structural factor in its fusion activity and to our knowledge, this study is the first example of direct distance measurements between the HFP and the lipid headgroups. Values of $r \sim 5-6 \AA$ were detected between the ${ }^{13} \mathrm{COs}$ of residues from A14 to G16 and the lipid ${ }^{31}$ Ps. These $r$ values support intimate association of the HFP and membranes containing either only phospholipids or phospholipids and cholesterol. The average $r$ for ${ }^{5} \mathrm{GALFLGFLG}{ }^{13} \mathrm{COs}$ was likely greater than $8 \AA(d \leq 25 \mathrm{~Hz})$ as evidenced by the significantly smaller $\left(\Delta S / S_{0}\right)^{\text {exp }}$, cf. Fig. 5, Fig 7 . Thus, relative to the ${ }^{5}$ GALFLGFLG residues, the ${ }^{14} \mathrm{AAG}$ residues are much closer to the lipid ${ }^{31} \mathrm{P}$.

The G5 to $\mathrm{G} 16{ }^{13} \mathrm{CO}$ chemical shift distributions of this study were consistent with a major population of HFP with $\beta$ strand conformation for these residues. This result correlated with previous studies which supported the following structural features: (1) $\beta$ strand HFP was fully extended between A1 and G16; (2) $\beta$ strand HFP formed hydrogen bonded oligomers or aggregates; and (3) a significant fraction of the oligomers have an antiparallel arrangement with adjacent strand crossing between F8 and L9 $(25,27-29,35,37,85,86)$. Some of these studies also supported conformational disorder at A21 $(27,28)$. Although there are some data supporting a population of parallel strand arrangement, "partial membrane insertion (PMI)" and "full membrane insertion (FMI)" models are only presented for the antiparallel arrangement, cf. Fig. 8 (29,35,87). There have been high-resolution structures for the $\sim 130$ residue "soluble ectodomain" region of gp41 which begins about ten residues C-terminal of the HFP and ends about twenty residues N-terminal of the gp41 transmembrane domain (8892). These structures showed trimeric gp 41 with the residues closest to the HFPs in a parallel in-register coiled-coil. Antiparallel HFP strand arrangement in the context of gp41 would then require at least two gp41 trimers. Strands from trimer $A\left(A_{1}, A_{2}, A_{3}\right)$ would be parallel to one another and strands from trimer $\mathrm{B}\left(\mathrm{B}_{1}, \mathrm{~B}_{2}, \mathrm{~B}_{3}\right)$ would be parallel to one another and an antiparallel interleaved strand arrangement could be formed as $\mathrm{A}_{1} \mathrm{~B}_{3} \mathrm{~A}_{2} \mathrm{~B}_{2} \mathrm{~A}_{3} \mathrm{~B}_{1}$. There is solidstate NMR evidence for the antiparallel arrangement of membrane-associated HFPs which were cross-linked at their C-termini (35).

For antiparallel strands between A1 and G16, the ${ }^{14} \mathrm{AAG}$ residues in both the PMI and FMI models are at the ends of the hydrogen-bonded oligomer and are closer to the lipid headgroups than residues ${ }^{5}$ GALFLGFLG. The F8 and L9 residues are at the center of the hydrogen-bonded oligomer and are most deeply membrane-inserted in all models. This result is consistent with 
the smallest $\left(\Delta S / S_{0}\right) \exp$ values observed for the HFP1- ${ }^{8} \mathrm{FLG}$ and HFP3- ${ }^{8} \mathrm{FLG}$ samples and with the large number of apolar sidechains in the central ${ }^{7}$ LFLGFL (L7 to L12) region. relative to the HFP1- ${ }^{8}$ FLG and HFP3 $-{ }^{8}$ FLG samples, the models also predict smaller $r$ and larger $\left(\Delta S / S_{0}\right)^{\exp }$ for the HFP2- ${ }^{5} \mathrm{GAL}$ and HFP2- ${ }^{11}$ FLG samples which generally correlates with the experimental data, cf. Fig. 5a-b. The models suggest small $r$ and significant $\left(\Delta S / S_{0}\right)$ expression for HFPs labeled at the N-terminal residues and future studies could examine samples labeled in this manner.

The PMI model in Fig. 8a would likely perturb the membrane and has some similarity with: (1) the PMI of extended conformation internal fusion peptides postulated from structures of dengue, Semliki forest, herpes, and vesicular stomatitis viral fusion proteins; (2) the PMI of helical influenza fusion peptide determined from electron spin resonance experiments; and (3) a PMI model based on the HFP-F8W fluorescence measurements $(37,61,62,93-96)$. However, the locations of lipids in the perturbed leaflet in the PMI model are not clear. For the FMI model of Fig. 8b, the positions of the lipids are more clear but there are non-hydrogen bonded CO and $\mathrm{NH}$ groups at the sheet edges with large Born energies. These energies would be reduced for a FMI $\beta$ barrel structure, Fig. 8c. There is correlation between the FMI model and the deep insertion of the Trp sidechain suggested from fluorescence studies of the HFP-F8W mutant $(36,37)$. In the context of gp41, individual HFP trimers would be on the same side of the membrane in the PMI model but would be on different sides of the membrane in the FMI model. It is not clear how this FMI trimer topology would relate to the positions of the viral membrane-anchored gp41 trimers and the host cell membranes. The free energy difference between the A1 to G16 FMI state and a non-inserted state is $\sim 3.9 \mathrm{~kJ} / \mathrm{mol}$ as calculated from the sum of individual residue free energy values derived from transmembrane helices (97). The calculated difference for the I4 to G13 sequence is $-2.3 \mathrm{~kJ} / \mathrm{mol}$ and leads to the general conclusion that the free energy calculations do not strongly distinguish between the PMI and FMI models. Future studies could discriminate between the PMI and FMI models using REDOR distance measurements between peptide nuclei and lipid acyl chain nuclei (51).

There are similarities between these PMI and FMI models of oligomeric $\beta$ strand HFP and PMI and FMI models which have been developed for a single HFP in a helical conformation (38, 39,98 ). Much of the experimental data for helical HFP insertion has been based on detergent rather than membrane samples and there has been support for both micelle surface location and micelle traversal by HFP (19-23). Our results on oligomeric $\beta$ strand HFP were consistent with the previous observations that the A15 and G16 residues of monomeric helical HFP were close to the water-micelle interface and that the F8 to G10 residues were furthest from this interface. Thus, there may be common features shared by the micelle and membrane locations of helical and $\beta$ strand HFP.

\section{Origin of $f$ and effects of cholesterol}

The HFP2- ${ }^{14}$ AAG and HFP4- ${ }^{14}$ A data could only be fit well with addition of the $f$ parameter which approximately reflected the fractional population of peptides whose labeled residues were close to the ${ }^{31} \mathrm{P}$. Analysis of ${ }^{13} \mathrm{CO}-{ }^{31} \mathrm{P}$ REDOR data of a membrane-associated antimicrobial peptide also required an $f$ parameter and the best-fit $f$ and $r$ values were similar to our results (51).

The membranes of host cells of HIV have cholesterol:lipid $\sim 0.45$ and the membranes of HIV have cholesterol:lipid $\sim 0.8(54,57)$. These data suggest that it is interesting to probe the effect of cholesterol on HFP location in the membrane. Similar values of $\left(\Delta S / S_{0}\right)^{\exp }$ were obtained for the ${ }^{5}$ GALFLGFLG residues in PC:PG and PC:PG:CHOL samples and the best-fit $r$ for the ${ }^{14} \mathrm{AAG}$ residues were comparable in both membrane compositions. These results suggest: (1) the inserted HFP population has similar location in membranes with or without cholesterol; and (2) the membrane location of the A14 to G16 residues may be similar in both helical and 
$\beta$ strand conformations because there appeared to be some helical conformation in PC:PG and negligible helical conformation in PC:PG:CHOL. There was a difference in best-fit $f$ for HFP2- ${ }^{14}$ AAG in PC:PG and PC:PG:CHOL with values of 0.45 and 0.32 , respectively. There are several potential explanations for this variation. First, the HFP/PC:PG samples likely had a small population of helical conformation which was absent in the HFP/PC:PG:CHOL samples and this helical population could have contributed to the larger $f$ in PC:PG. Second, the presumably gel phase PC:PG and the liquid-ordered phase PC:PG:CHOL had lateral molecular densities of $\sim 0.213 \AA^{-2}$ and $\sim 0.256 \AA^{-2}$ as calculated from gel-phase PC and PG areas of $47 \AA^{2}$, liquid-ordered PC and PG areas of $40 \AA^{2}$, and cholesterol area of $37 \AA^{2}$ (60, $71,99,100)$. The denser packing in PC:PG:CHOL could have shifted an inserted HFP:surface HFP equilibrium to surface HFP and led to reduced $f$. Finally, relative to the PC:PG sample, there was likely a reduced number of phospholipids close to the ${ }^{14} \mathrm{AAG}$ residues in the PC:PG:CHOL sample because of statistical substitution of nearby phospholipids with cholesterol. This lipid dilution may have also reduced $f$ in the PC:PG:CHOL sample.

In summary, ${ }^{13} \mathrm{CO}-{ }^{31} \mathrm{P}$ distance measurements have demonstrated close proximity of the ${ }^{14} \mathrm{AAG}$ residues to the lipid ${ }^{31} \mathrm{P}$ for a significant fraction of membrane-associated HFP. This proximity was observed both for membranes with and without cholesterol. The chemical shifts of this study as well as results from previous studies correlated with a predominant population of HFP with $\beta$ strand conformation. Models of partial and full insertion of $\beta$ strands are proposed which are consistent with the experimental data. Although there have been numerous previous observations of $\beta$ strand HFP, the role of this conformation in fusion has been controversial $(14,16,18,31,45)$. The present study demonstrates that $\beta$ strand HFP is in intimate contact with membranes and merits serious consideration as a fusogenic conformation.

Interesting future work could include studies of cross-linked HFPs which are thought to mimic the HFP oligomeric topology in the gp41 protein and which have increased fusion rates relative to the non-cross-linked HFPs of the present study (34). There may be a distinct membrane location of the cross-linked HFPs which correlates with their fast fusion rate. It is also known that the cross-linked HFP trimer will form helical or $\beta$ strand conformation in membranes without or with cholesterol, respectively, so that studies of the trimer in different membrane compositions can provide information about the conformational dependence of peptide location in membranes (35).

\section{Supplementary Material}

Refer to Web version on PubMed Central for supplementary material.

\section{ABBREVIATIONS}

${ }^{14} \mathrm{AAG}$, residues A14, A15, and G16

${ }^{13} \mathrm{CO},{ }^{13} \mathrm{C}$ labeled carbonyl

$d$, magnitude of ${ }^{13} \mathrm{C}-{ }^{31} \mathrm{P}$ dipolar coupling

DPPC- ${ }^{13} \mathrm{C}, 1$,2-dipalmitoyl-sn-glycero-3-phosphocholine with ${ }^{13} \mathrm{C}$ labeling at the both carbonyl sites

DTPC, 1,2-di-O-tetradecyl-sn-glycero-3-phosphocholine

DTPG, 1,2-di-O-tetradecyl-sn-glycero-3-[phospho-rac-(1-glycerol)]

$f$, fraction of ${ }^{13} \mathrm{COs}$ close to ${ }^{31} \mathrm{Ps}$

FMI, full membrane insertion

${ }^{5}$ GALFLGFLG, residues G5, A6, L7, F8, L9, G10, F11, L12, and G13

HEPES, N-(2-hydroxy-ethyl)piperazine-N'-2-ethanesulfonic acid

HFP, HIV fusion peptide

HFP1, AVGIGALFLGFLGAAGSTMGARS-NH 
HFP1- ${ }^{8}$ FLG, HFP $1{ }^{13} \mathrm{CO}$ labeled at F8, L9, and G10

HFP2, AVGIGALFLGFLGAAGSTMGARSKKK-NH 2

HFP2- ${ }^{5} \mathrm{GAL}$, HFP2 ${ }^{13} \mathrm{CO}$ labeled at G5, A6, and L7

HFP2- $-{ }^{11}$ FLG, HFP2 ${ }^{13} \mathrm{CO}$ labeled at F11, L12, and G13

HFP2- ${ }^{14}$ AAG, HFP $2{ }^{13} \mathrm{CO}$ labeled at A14, A15, and G16

HFP3, AVGIGALFLGFLGAAGSTMGARSKKKA $\beta$

HFP3- ${ }^{8} \mathrm{FLG}, \mathrm{HFP} 3{ }^{13} \mathrm{CO}$ labeled at F8, L9, and G10

HFP4, AVGIGALFLGFLGAAGSTMGARSWKKKKKKA $\beta$

HFP4- ${ }^{6} \mathrm{~A}, \mathrm{HFP} 4{ }^{13} \mathrm{CO}$ labeled at A6

HFP4- ${ }^{14} \mathrm{~A}, \mathrm{HFP} 4{ }^{13} \mathrm{CO}$ labeled at A14

$\mathrm{HIV}$, human immunodeficiency virus

IR, infrared

${ }^{7}$ LFLGFL, residues L7, F8, L9, G10, F11, and L12

MAS, magic angle spinning

NMR, nuclear magnetic resonance

PC:PG 4:1 DTPC:DTPG

PC:PG:CHOL 8:2:5 DTPC:DTPG:cholesterol

PMI, partial membrane insertion

$r,{ }^{13} \mathrm{C}-{ }^{31} \mathrm{P}$ internuclear distance

REDOR, rotational-echo double resonance

$\tau$, duration of dephasing period

TFA, trifluoroacetic acid

\section{ACKNOWLEDGEMENT}

Dr. Richard Venable provided the coordinates of crystalline DMPC and gel-phase DPPC. We acknowledge Dr. Michael Feig for useful discussions about the insertion models.

\section{REFERENCES}

1. Hernandez LD, Hoffman LR, Wolfsberg TG, White JM. Virus-cell and cell-cell fusion. Annu. Rev. Cell. Dev. Biol 1996;12:627-661. [PubMed: 8970739]

2. Eckert DM, Kim PS. Mechanisms of viral membrane fusion and its inhibition. Annu. Rev. Biochem 2001;70:777-810. [PubMed: 11395423]

3. Jahn R, Lang T, Sudhof TC. Membrane fusion. Cell 2003;112:519-533. [PubMed: 12600315]

4. Blumenthal R, Clague MJ, Durell SR, Epand RM. Membrane fusion. Chem. Rev 2003;103:53-69. [PubMed: 12517181]

5. Bentz J. Membrane fusion mediated by coiled coils: a hypothesis. Biophys. J 2000;78:886-900. [PubMed: 10653801]

6. Chernomordik LV, Kozlov MM. Protein-lipid interplay in fusion and fission of biological membranes. Annu. Rev. Biochem 2003;72:175-207. [PubMed: 14527322]

7. Cohen FS, Melikyan GB. The energetics of membrane fusion from binding, through hemifusion, pore formation, and pore enlargement. J. Membrane Biol 2004;199:1-14. [PubMed: 15366419]

8. Turner BG, Summers MF. Structural biology of HIV. J. Mol. Biol 1999;285:1-32. [PubMed: 9878383]

9. Colman PM, Lawrence MC. The structural biology of type I viral membrane fusion. Nat. Rev. Mol. Cell Biol 2003;4:309-319. [PubMed: 12671653]

10. Freed EO, Myers DJ, Risser R. Characterization of the fusion domain of the human immunodeficiency virus type 1 envelope glycoprotein gp41. Proc. Natl. Acad. Sci. U.S.A 1990;87:4650-4654. [PubMed: 2191297]

11. Freed EO, Delwart EL, Buchschacher GL Jr, Panganiban AT. A mutation in the human immunodeficiency virus type 1 transmembrane glycoprotein gp41 dominantly interferes with fusion and infectivity. Proc. Natl. Acad. Sci. U.S.A 1992;89:70-74. [PubMed: 1729720] 
12. Schaal H, Klein M, Gehrmann P, Adams O, Scheid A. Requirement of N-terminal amino acid residues of gp41 for human immunodeficiency virus type 1-mediated cell fusion. J. Virol 1995;69:3308-3314. [PubMed: 7745678]

13. Delahunty MD, Rhee I, Freed EO, Bonifacino JS. Mutational analysis of the fusion peptide of the human immunodeficiency virus type 1: identification of critical glycine residues. Virology 1996;218:94-102. [PubMed: 8615045]

14. Durell SR, Martin I, Ruysschaert JM, Shai Y, Blumenthal R. What studies of fusion peptides tell us about viral envelope glycoprotein-mediated membrane fusion. Mol. Membr. Biol 1997;14:97-112. [PubMed: 9394290]

15. Kliger Y, Aharoni A, Rapaport D, Jones P, Blumenthal R, Shai Y. Fusion peptides derived from the HIV type 1 glycoprotein 41 associate within phospholipid membranes and inhibit cell-cell fusion. Structure-function study. J. Biol. Chem 1997;272:13496-13505. [PubMed: 9153194]

16. Pereira FB, Goni FM, Muga A, Nieva JL. Permeabilization and fusion of uncharged lipid vesicles induced by the HIV-1 fusion peptide adopting an extended conformation: dose and sequence effects. Biophys. J 1997;73:1977-1986. [PubMed: 9336193]

17. Pritsker M, Rucker J, Hoffman TL, Doms RW, Shai Y. Effect of nonpolar substitutions of the conserved Phe11 in the fusion peptide of HIV-1 gp41 on its function, structure, and organization in membranes. Biochemistry 1999;38:11359-11371. [PubMed: 10471286]

18. Martin I, Schaal H, Scheid A, Ruysschaert JM. Lipid membrane fusion induced by the human immunodeficiency virus type $1 \mathrm{gp} 41 \mathrm{~N}$-terminal extremity is determined by its orientation in the lipid bilayer. J. Virol 1996;70:298-304. [PubMed: 8523539]

19. Chang DK, Cheng SF, Chien WJ. The amino-terminal fusion domain peptide of human immunodeficiency virus type $1 \mathrm{gp} 41$ inserts into the sodium dodecyl sulfate micelle primarily as a helix with a conserved glycine at the micelle-water interface. J. Virol 1997;71:6593-6602. [PubMed: 9261381]

20. Jaroniec CP, Kaufman JD, Stahl SJ, Viard M, Blumenthal R, Wingfield PT, Bax A. Structure and dynamics of micelle-associated human immunodeficiency virus gp41 fusion domain. Biochemistry 2005;44:16167-16180. [PubMed: 16331977]

21. Morris KF, Gao XF, Wong TC. The interactions of the HIV gp41 fusion peptides with zwitterionic membrane mimics determined by NMR spectroscopy. Biochim. Biophys. Acta-Biomembranes 2004;1667:67-81.

22. Chang DK, Cheng SF. Determination of the equilibrium micelle-inserting position of the fusion peptide of gp41 of human immunodeficiency virus type 1 at amino acid resolution by exchange broadening of amide proton resonances. J. Biomol. NMR 1998;12:549-552. [PubMed: 9862130]

23. Langham A, Kaznessis Y. Simulation of the N-terminus of HIV-1 glycoprotein 41000 fusion peptide in micelles. J. Pept. Sci 2005;11:215-224. [PubMed: 15635657]

24. Rafalski M, Lear JD, DeGrado WF. Phospholipid interactions of synthetic peptides representing the N-terminus of HIV gp41. Biochemistry 1990;29:7917-7922. [PubMed: 2261447]

25. Nieva JL, Nir S, Muga A, Goni FM, Wilschut J. Interaction of the HIV-1 fusion peptide with phospholipid vesicles: different structural requirements for fusion and leakage. Biochemistry 1994;33:3201-3209. [PubMed: 8136355]

26. Peisajovich SG, Epand RF, Pritsker M, Shai Y, Epand RM. The polar region consecutive to the HIV fusion peptide participates in membrane fusion. Biochemistry 2000;39:1826-1833. [PubMed: 10677233]

27. Yang J, Gabrys CM, Weliky DP. Solid-state nuclear magnetic resonance evidence for an extended beta strand conformation of the membrane-bound HIV-1 fusion peptide. Biochemistry 2001;40:8126-8137. [PubMed: 11434782]

28. Bodner, ML. Ph. D. thesis. East Lansing: Michigan State University; 2006. Solid state nuclear magnetic resonance of the HIV-1 and influenza fusion peptides associated with membranes.

29. Yang J, Weliky DP. Solid state nuclear magnetic resonance evidence for parallel and antiparallel strand arrangements in the membrane-associated HIV-1 fusion peptide. Biochemistry 2003;42:11879-11890. [PubMed: 14529300]

30. Gordon LM, Curtain CC, Zhong YC, Kirkpatrick A, Mobley PW, Waring AJ. The amino-terminal peptide of HIV-1 glycoprotein 41 interacts with human erythrocyte membranes: peptide 
conformation, orientation and aggregation. Biochim. Biophys. Acta 1992;1139:257-274. [PubMed: 1355364]

31. Epand RM. Fusion peptides and the mechanism of viral fusion. Biochim. Biophys. ActaBiomembranes 2003;1614:116-121.

32. Afonin S, Glaser RW, Berditchevskaia M, Wadhwani P, Guhrs KH, Mollmann U, Perner A, Ulrich AS. 4-fluorophenylglycine as a label for ${ }^{19} \mathrm{~F}$ NMR structure analysis of membrane-associated peptides. Chembiochem 2003;4:1151-1163. [PubMed: 14613106]

33. Hofmann MW, Weise K, Ollesch J, Agrawal P, Stalz H, Stelzer W, Hulsbergen F, de Groot H, Gerwert K, Reed J, Langosch D. De novo design of conformationally flexible transmembrane peptides driving membrane fusion. Proc. Natl. Acad. Sci. U.S.A 2004;101:14776-14781. [PubMed: 15456911]

34. Yang R, Prorok M, Castellino FJ, Weliky DP. A trimeric HIV-1 fusion peptide construct which does not self-associate in aqueous solution and which has 15 -fold higher membrane fusion rate. J. Am. Chem. Soc 2004;126:14722-14723. [PubMed: 15535688]

35. Zheng Z, Yang R, Bodner ML, Weliky DP. Conformational flexibility and strand arrantements of the membrane-associated HIV fusion peptide trimer probed by solid-state NMR spectroscopy. Biochemistry 2006;45:12960-12975. [PubMed: 17059213]

36. Agirre A, Flach C, Goni FM, Mendelsohn R, Valpuesta JM, Wu FJ, Nieva JL. Interactions of the HIV-1 fusion peptide with large unilamellar vesicles and monolayers. A cryo-TEM and spectroscopic study. Biochim. Biophys. Acta-Biomembranes 2000;1467:153-164.

37. Haque ME, Koppaka V, Axelsen PH, Lentz BR. Properties and structures of the influenza and HIV fusion peptides on lipid membranes: Implications for a role in fusion. Biophys. J 2005;89:3183-3194. [PubMed: 16183890]

38. Kamath S, Wong TC. Membrane structure of the human immunodeficiency virus gp41 fusion domain by molecular dynamics simulation. Biophys. J 2002;83:135-143. [PubMed: 12080106]

39. Maddox MW, Longo ML. Conformational partitioning of the fusion peptide of HIV-1 gp41 and its structural analogs in bilayer membranes. Biophys. J 2002;83:3088-3096. [PubMed: 12496080]

40. Grobner G, Glaubitz C, Watts A. Probing membrane surfaces and the location of membraneembedded peptides by ${ }^{13}$ C MAS NMR using lanthanide ions. J. Mag. Reson 1999;141:335-339.

41. Buffy JJ, Hong T, Yamaguchi S, Waring AJ, Lehrer RI, Hong M. Solid-state NMR investigation of the depth of insertion of protegrin-1 in lipid bilayers using paramagnetic $\mathrm{Mn}^{2+}$ Biophys. $\mathrm{J}$ 2003;85:2363-2373. [PubMed: 14507700]

42. Vogel A, Scheidt HA, Huster D. The distribution of lipid attached spin probes in bilayers: Application to membrane protein topology. Biophys. J 2003;85:1691-1701. [PubMed: 12944284]

43. Tian CL, Gao PF, Pinto LH, Lamb RA, Cross TA. Initial structural and dynamic characterization of the M2 protein transmembrane and amphipathic helices in lipid bilayers. Prot. Sci 2003;12:25972605.

44. Gallagher GJ, Hong M, Thompson LK. Solid-state NMR spin diffusion for measurement of membrane-bound peptide structure: Gramicidin A. Biochemistry 2004;43:7899-7906. [PubMed: 15196034]

45. Grage SL, Afonin S, Grune M, Ulrich AS. Interaction of the fusogenic peptide B18 in its amyloidstate with lipid membranes studied by solid state NMR. Chem. Phys. Lipids 2004;132:65-77. [PubMed: 15530449]

46. Henzler-Wildman KA, Martinez GV, Brown MF, Ramamoorthy A. Perturbation of the hydrophobic core of lipid bilayers by the human antimicrobial peptide LL-37. Biochemistry 2004;43:8459-8469. [PubMed: 15222757]

47. Abu-Baker S, Qi XY, Newstadt J, Lorigan GA. Structural changes in a binary mixed phospholipid bilayer of DOPG and DOPS upon saposin $\mathrm{C}$ interaction at acidic $\mathrm{pH}$ utilizing ${ }^{31} \mathrm{P}$ and ${ }^{2} \mathrm{H}$ solid-state NMR spectroscopy. Biochim. Biophys. Acta-Biomembranes 2005;1717:58-66.

48. Zhang WY, Smith SO. Mechanism of penetration of Antp(43-58) into membrane bilayers. Biochemistry 2005;44:10110-10118. [PubMed: 16042388]

49. Sharpe S, Yau WM, Tycko R. Structure and dynamics of the HIV-1 Vpu transmembrane domain revealed by solid-state NMR with magic-angle spinning. Biochemistry 2006;45:918-933. [PubMed: $16411768]$ 
50. Harada E, Todokoro Y, Akutsu H, Fujiwara T. Detection of peptide-phospholipid interaction sites in bilayer membranes by ${ }^{13} \mathrm{C}$ NMR spectroscopy: Observation of ${ }^{2} \mathrm{H} /{ }^{31} \mathrm{P}$-selective ${ }^{1} \mathrm{H}$-depolarization under magic-angle spinning. J. Am. Chem. Soc 2006;128:10654-10655. [PubMed: 16910640]

51. Toke O, Maloy WL, Kim SJ, Blazyk J, Schaefer J. Secondary structure and lipid contact of a peptide antibiotic in phospholipid Bilayers by REDOR. Biophys. J 2004;87:662-674. [PubMed: 15240500]

52. Cegelski L, Rice CV, O'Connor RD, Caruano AL, Tochtrop GP, Cai ZY, Covey DF, Schaefer J. Mapping the locations of estradiol and potent neuroprotective analogues in phospholipid bilayers by REDOR. Drug Develop. Res 2005;66:93-102.

53. Matsuoka S, Ikeuchi H, Matsumori N, Murata M. Dominant formation of a single-length channel by amphotericin $\mathrm{B}$ in dimyristoylphosphatidylcholine membrane evidenced by ${ }^{13} \mathrm{C}-{ }^{13} \mathrm{P}$ rotational echo double resonance. Biochemistry 2005;44:704-710. [PubMed: 15641796]

54. Aloia RC, Tian H, Jensen FC. Lipid composition and fluidity of the human immunodeficiency virus envelope and host cell plasma membranes. Proc. Natl. Acad. Sci. U.S.A 1993;90:5181-5185. [PubMed: 8389472]

55. Yang J, Parkanzky PD, Bodner ML, Duskin CG, Weliky DP. Application of REDOR subtraction for filtered MAS observation of labeled backbone carbons of membrane-bound fusion peptides. J. Magn. Reson 2002;159:101-110. [PubMed: 12482688]

56. Wasniewski CM, Parkanzky PD, Bodner ML, Weliky DP. Solid-state nuclear magnetic resonance studies of HIV and influenza fusion peptide orientations in membrane bilayers using stacked glass plate samples. Chem. Phys. Lipids 2004;132:89-100. [PubMed: 15530451]

57. Brugger B, Glass B, Haberkant P, Leibrecht I, Wieland FT, Krasslich HG. The HIV lipidome: A raft with an unusual composition. Proc. Natl. Acad. Sci. U.S.A 2006;103:2641-2646. [PubMed: 16481622]

58. Gullion T, Schaefer J. Rotational-echo double-resonance NMR. J. Magn. Reson 1989;81:196-200.

59. Yang J, Prorok M, Castellino FJ, Weliky DP. Oligomeric $\beta$-structure of the membrane-bound HIV-1 fusion peptide formed from soluble monomers. Biophys. J 2004;87:1951-1963. [PubMed: 15345571]

60. Cevc G. How membrane chain melting properties are regulated by the polar surface of the lipid bilayer. Biochemistry 1987;26:6305-6310. [PubMed: 3427005]

61. Macosko JC, Kim CH, Shin YK. The membrane topology of the fusion peptide region of influenza hemagglutinin determined by spin-labeling EPR. J. Mol. Biol 1997;267:1139-1148. [PubMed: 9150402]

62. Han X, Bushweller JH, Cafiso DS, Tamm LK. Membrane structure and fusion-triggering conformational change of the fusion domain from influenza hemagglutinin. Nat. Struct. Biol 2001;8:715-720. [PubMed: 11473264]

63. Afonin S, Dur UHN, Glaser RW, Ulrich AS. 'Boomerang'-like insertion of a fusogenic peptide in a lipid membrane revealed by solid-state ${ }^{19}$ F NMR. Magn. Reson. Chem 2004;42:195-203. [PubMed: 14745800]

64. Yang J, Parkanzky PD, Khunte BA, Canlas CG, Yang R, Gabrys CM, Weliky DP. Solid state NMR measurements of conformation and conformational distributions in the membrane-bound HIV-1 fusion peptide. J. Mol. Graph. Model 2001;19:129-135. [PubMed: 11381522]

65. Morcombe CR, Zilm KW. Chemical shift referencing in MAS solid state NMR. J. Magn. Reson 2003;162:479-486. [PubMed: 12810033]

66. Zhang HY, Neal S, Wishart DS. RefDB: A database of uniformly referenced protein chemical shifts. J. Biomol. NMR 2003;25:173-195. [PubMed: 12652131]

67. Igumenova TI, Wand AJ, McDermott AE. Assignment of the backbone resonances for microcrystalline ubiquitin. J. Am. Chem. Soc 2004;126:5323-5331. [PubMed: 15099118]

68. Franks WT, Zhou DH, Wylie BJ, Money BG, Graesser DT, Frericks HL, Sahota G, Rienstra CM. Magic-angle spinning solid-state NMR spectroscopy of the $\beta 1$ immunoglobulin binding domain of protein $\mathrm{G}(\mathrm{GB} 1):{ }^{15} \mathrm{~N}$ and ${ }^{13} \mathrm{C}$ chemical shift assignments and conformational analysis. J. Am. Chem. Soc 2005;127:12291-12305. [PubMed: 16131207]

69. Marulanda D, Tasayco ML, Cataldi M, Arriaran V, Polenova T. Resonance assignments and secondary structure analysis of E-coli thioredoxin by magic angle spinning solid-state NMR spectroscopy. J. Phys. Chem. B 2005;109:18135-18145. [PubMed: 16853329] 
70. Bodner ML, Gabrys CM, Parkanzky PD, Yang J, Duskin CA, Weliky DP. Temperature dependence and resonance assignment of ${ }^{13} \mathrm{C}$ NMR spectra of selectively and uniformly labeled fusion peptides associated with membranes. Magn. Reson. Chem 2004;42:187-194. [PubMed: 14745799]

71. Bloom M, Evans E, Mouritsen OG. Physical properties of the fluid lipid-bilayer component of cell membranes: a perspective. Q. Rev. Biophys 1991;24:293-397. [PubMed: 1749824]

72. Gabrys CM, Yang J, Weliky DP. Analysis of local conformation of membrane-bound and polycrystalline peptides by two-dimensional slow-spinning rotor-synchronized MAS exchange spectroscopy. J. Biomol. NMR 2003;26:49-68. [PubMed: 12766402]

73. McDowell LM, Holl SM, Qian SJ, Li E, Schaefer J. Intertryptophan distances in rat cellular retinolbinding Protein Ii by solid-state NMR. Biochemistry 1993;32:4560-4563. [PubMed: 8485132]

74. Anderson RC, Gullion T, Joers JM, Shapiro M, Villhauer EB, Weber HP. Conformation of $\left[1-{ }^{13} \mathrm{C}\right.$, ${ }^{15} \mathrm{~N}$ ]acetyl-L-carnitine. Rotational-echo, double-resonance nuclear magnetic resonance spectroscopy. J. Am. Chem. Soc 1995;117:10546-10550.

75. Gullion T. Introduction to rotational-echo, double-resonance NMR. Concept Magnetic Res 1998;10:277-289.

76. Bennett AE, Rienstra CM, Auger M, Lakshmi KV, Griffin RG. Heteronuclear decoupling in rotating solids. J. Chem. Phys 1995;103:6951-6958.

77. Bevington, PR.; Robinson, DK. Data Reduction and Error Analysis for the Physical Sciences. 2nd ed.. Boston: McGraw-Hill; 1992.

78. Mueller KT. Analytic solutions for the time evolution of dipolar-dephasing NMR signals. J. Magn. Reson. Ser. A 1995;113:81-93.

79. Raghunathan V, Gibson JM, Goobes G, Popham JM, Louie EA, Stayton PS, Drobny GP. Homonuclear and heteronuclear NMR studies of a statherin fragment bound to hydroxyapatite crystals. J. Phys. Chem. B 2006;110:9324-9332. [PubMed: 16671751]

80. Pearson RH, Pascher I. Molecular structure of lecithin dihydrate. Nature 1979;281:499-501. [PubMed: 492310]

81. Pascher I, Sundell S, Harlos K, Eibl H. Conformation and packing properties of membrane lipids: The crystal structure of sodium dimyristoylphosphatidylglycerol. Biochim. Biophys. Acta 1987;896:77-88. [PubMed: 3790589]

82. Venable RM, Brooks BR, Pastor RW. Molecular dynamics simulations of gel $\left(\mathrm{L}_{\beta I}\right)$ phase lipid bilayers in constant pressure and constant surface area ensembles. J. Chem. Phys 2000;112:48224832.

83. Bennett AE, Ok JH, Griffin RG, Vega S. Chemical-shift correlation spectroscopy in rotating solids - radio frequency-driven dipolar recoupling and longitudinal exchange. J. Chem. Phys 1992;96:86248627.

84. Gullion T, Vega S. A simple magic angle spinning NMR experiment for the dephasing of rotational echoes of dipolar coupled homonuclear spin pairs. Chem. Phys. Lett 1992;194:423-428.

85. Gordon LM, Mobley PW, Pilpa R, Sherman MA, Waring AJ. Conformational mapping of the Nterminal peptide of HIV-1 gp41 in membrane environments using 13C-enhanced Fourier transform infrared spectroscopy. Biochim. Biophys. Acta-Biomembranes 2002;1559:96-120.

86. Castano S, Desbat B. Structure and orientation study of fusion peptide FP23 of gp41 from HIV-1 alone or inserted into various lipid membrane models (mono-, bi- and multibi-layers) by FT-IR spectroscopies and Brewster angle microscopy. Biochim. Biophys. Acta-Biomembranes 2005;1715:81-95.

87. Sackett K, Shai Y. The HIV fusion peptide adopts intermolecular parallel $\beta$-sheet structure in membranes when stabilized by the adjacent $\mathrm{N}$-terminal heptad repeat: A ${ }^{13} \mathrm{C}$ FTIR study. J. Mol. Biol 2005;350:790-805. [PubMed: 15964015]

88. Chan DC, Fass D, Berger JM, Kim PS. Core structure of gp41 from the HIV envelope glycoprotein. Cell 1997;89:263-273. [PubMed: 9108481]

89. Weissenhorn W, Dessen A, Harrison SC, Skehel JJ, Wiley DC. Atomic structure of the ectodomain from HIV-1 gp41. Nature 1997;387:426-430. [PubMed: 9163431]

90. Tan K, Liu J, Wang J, Shen S, Lu M. Atomic structure of a thermostable subdomain of HIV-1 gp41. Proc. Natl. Acad. Sci. U.S.A 1997;94:12303-12308. [PubMed: 9356444] 
91. Caffrey M, Cai M, Kaufman J, Stahl SJ, Wingfield PT, Covell DG, Gronenborn AM, Clore GM. Three-dimensional solution structure of the $44 \mathrm{kDa}$ ectodomain of SIV gp41. EMBO J 1998; 17:45724584. [PubMed: 9707417]

92. Yang ZN, Mueser TC, Kaufman J, Stahl SJ, Wingfield PT, Hyde CC. The crystal structure of the SIV gp41 ectodomain at 1.47 A resolution. J. Struct. Biol 1999;126:131-144. [PubMed: 10388624]

93. Modis Y, Ogata S, Clements D, Harrison SC. Structure of the dengue virus envelope protein after membrane fusion. Nature 2004;427:313-319. [PubMed: 14737159]

94. Gibbons DL, Vaney MC, Roussel A, Vigouroux A, Reilly B, Lepault J, Kielian M, Rey FA. Conformational change and protein protein interactions of the fusion protein of Semliki Forest virus. Nature 2004;427:320-325. [PubMed: 14737160]

95. Roche S, Bressanelli S, Rey FA, Gaudin Y. Crystal structure of the low-pH form of the vesicular stomatitis virus glycoprotein G. Science 2006;313:187-191. [PubMed: 16840692]

96. Heldwein EE, Lou H, Bender FC, Cohen GH, Eisenberg RJ, Harrison SC. Crystal structure of glycoprotein B from herpes simplex virus 1. Science 2006;313:217-220. [PubMed: 16840698]

97. Hessa T, Kim H, Bihlmaier K, Lundin C, Boekel J, Andersson H, Nilsson I, White SH, von Heijne G. Recognition of transmembrane helices by the endoplasmic reticulum translocon. Nature 2005;433:377-381. [PubMed: 15674282]

98. Charloteaux B, Lorin A, Crowet JM, Stroobant V, Lins L, Thomas A, Brasseur R. The N-terminal 12 residue long peptide of HIV gp41 is the minimal peptide sufficient to induce significant T-celllike membrane destabilization in vitro. J. Mol. Biol 2006;359:597-609. [PubMed: 16677669]

99. Smaby JM, Brockman HL, Brown RE. Cholesterol's interfacial interactions with sphingomyelins and phosphatidylcholines: Hydrocarbon chain structure determines the magnitude of condensation. Biochemistry 1994;33:9135-9142. [PubMed: 8049216]

100. Tristram-Nagle S, Liu YF, Legleiter J, Nagle JF. Structure of gel phase DMPC determined by Xray diffraction. Biophys. J 2002;83:3324-3335. [PubMed: 12496100] 

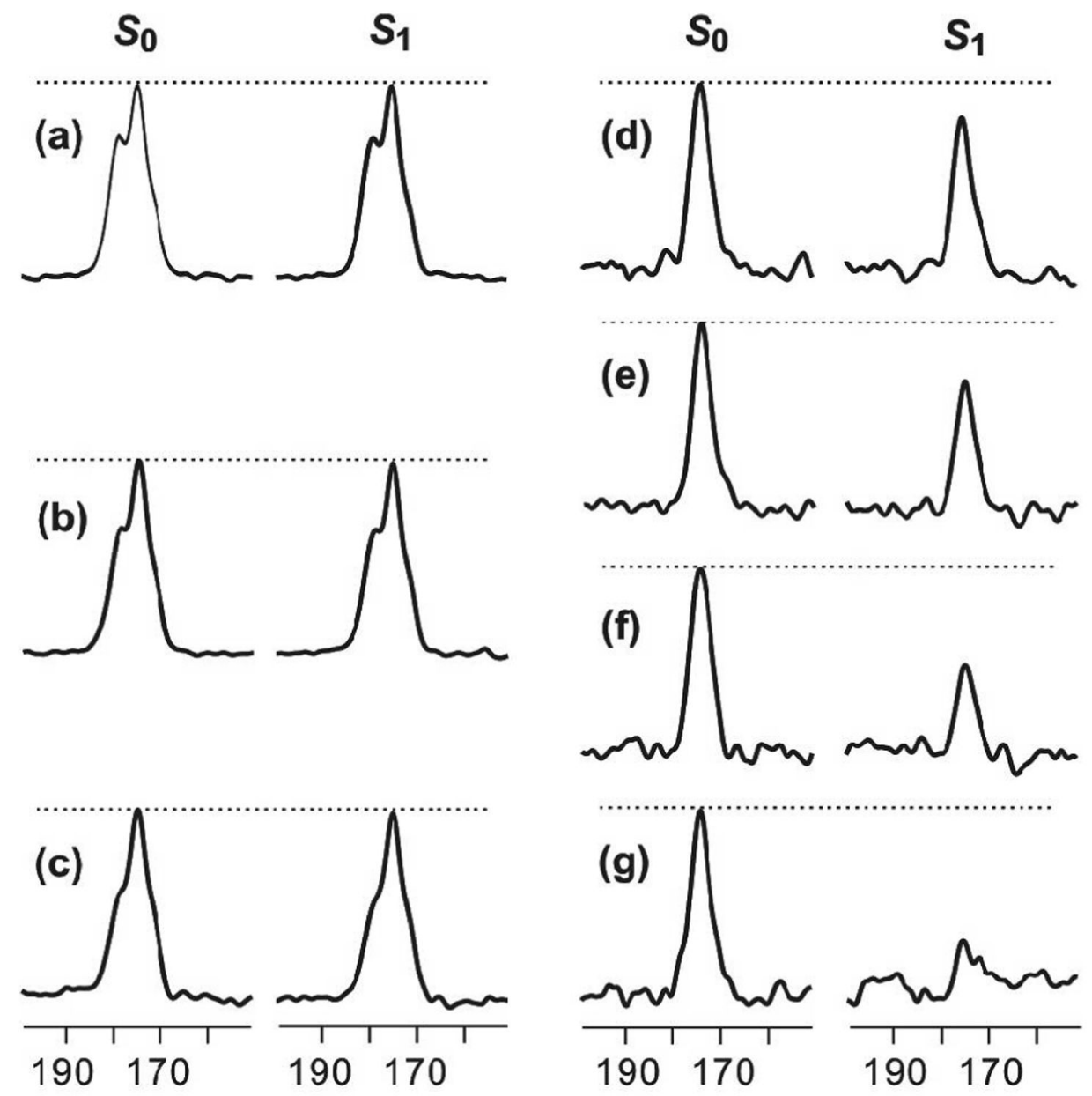

${ }^{13} \mathrm{C}$ Chemical Shift (ppm)

Figure 1.

${ }^{13} \mathrm{CO}-{ }^{31} \mathrm{P}$ REDOR spectra of $(\mathrm{a}-\mathrm{c})$ lyophilized HFP2- ${ }^{11} \mathrm{FLG}$ and $(\mathrm{d}-\mathrm{g})$ the HFP4:DPPC- ${ }^{13} \mathrm{C}$ sample. The left and right spectra in each pair of ${ }^{13} \mathrm{C}$-detected spectra are $S_{0}$ and $S_{1}$ spectra, respectively. The dotted lines are drawn for visual comparison of $S_{0}$ and $S_{1}$ peak intensities. Each spectrum was processed with $200 \mathrm{~Hz}$ Gaussian line broadening and baseline correction. The $\tau$ values and numbers of $S_{0}$ or $S_{1}$ scans in each pair of spectra were: a, $1 \mathrm{~ms}, 120 ; \mathrm{b}, 11$ ms, 126; c, 19 ms, 138; d, 1 ms, 8; e, 7 ms, 56; f, 13 ms, 104; g, 19 ms, 152. 




Figure 2.

$\left(\Delta S / S_{0}\right)^{\exp }$ (vertical lines with error bars) and best-fit $\left(\Delta S / S_{0}\right)^{\text {sim }}$ (diamonds) vs dephasing time $(\tau)$ for the HFP4/DPPC-1- ${ }^{13} \mathrm{C}$ sample. Lines are drawn between points with adjacent values of $\tau$. Each $\left(\Delta S / S_{0}\right)^{\exp }$ valuewas obtained from a $1 \mathrm{ppm}$ integration region centered at $173 \mathrm{ppm}$. The total $\left(S_{0}+S_{1}\right)$ numbers of scans for $\tau=1,3,5,7,9,11,13,15,17$ and 19 ms were 16, 48, $80,112,144,176,208,240,272$ and 304 , respectively. The displayed best-fit $\left(\Delta S / S_{0}\right)^{s i m}$ values corresponded to $d=68 \mathrm{~Hz}$ and $r=5.6 \AA$. 

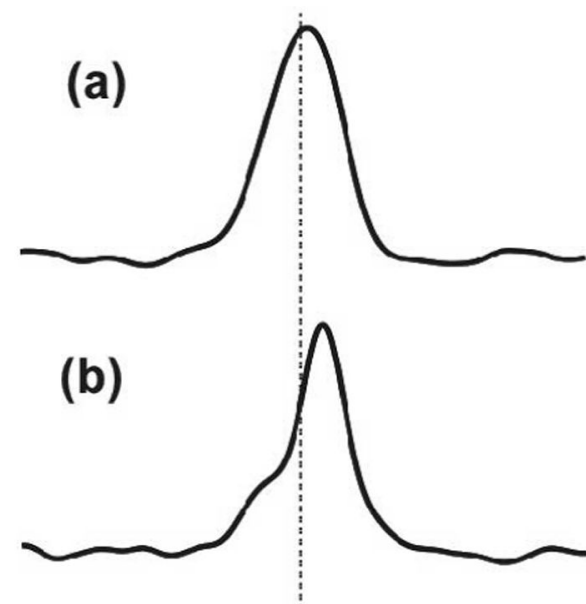

^

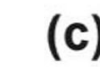

(c)

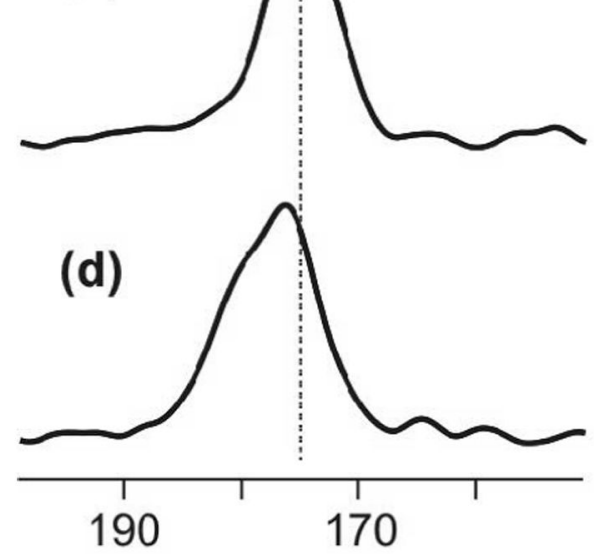

${ }^{13} \mathrm{C}$ Chemical Shift (ppm)
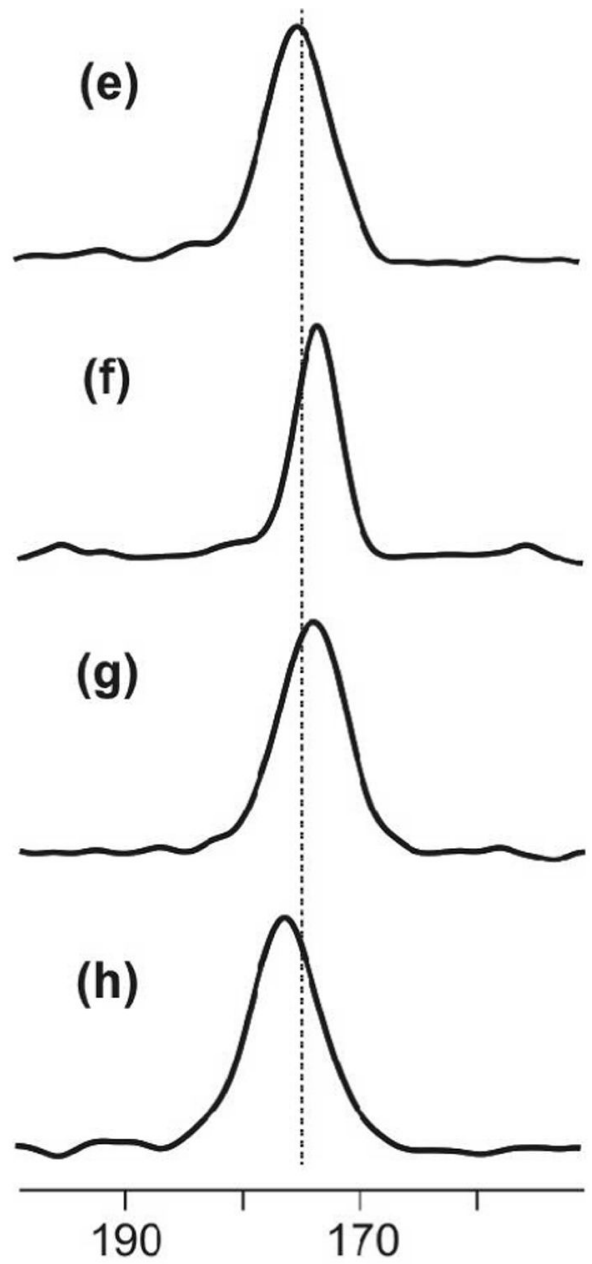

170

Figure 3.

$S_{0}$ spectra for membrane-associated HFP with peptide:lipid $\sim 0.04$. The dotted lines are at 175 $\mathrm{ppm}$. All spectra were obtained with $\tau=2 \mathrm{~ms}$ and were processed with $200 \mathrm{~Hz}$ Gaussian line broadening and baseline correction. The membrane composition for samples a-d was PC:PG and the membrane composition for samples e-h was PC:PG:CHOL. The peptides were: a, e, HFP2- ${ }^{5}$ GAL; $b$, f, HFP3- ${ }^{8}$ FLG; c, g, HFP2- ${ }^{11}$ FLG; and d, h HFP2- ${ }^{14}$ AAG. The numbers of scans summed to obtain spectra a-h were 4823, 3867, 4823, 8500, 3259, 1001, 4320 and 6992, respectively. 

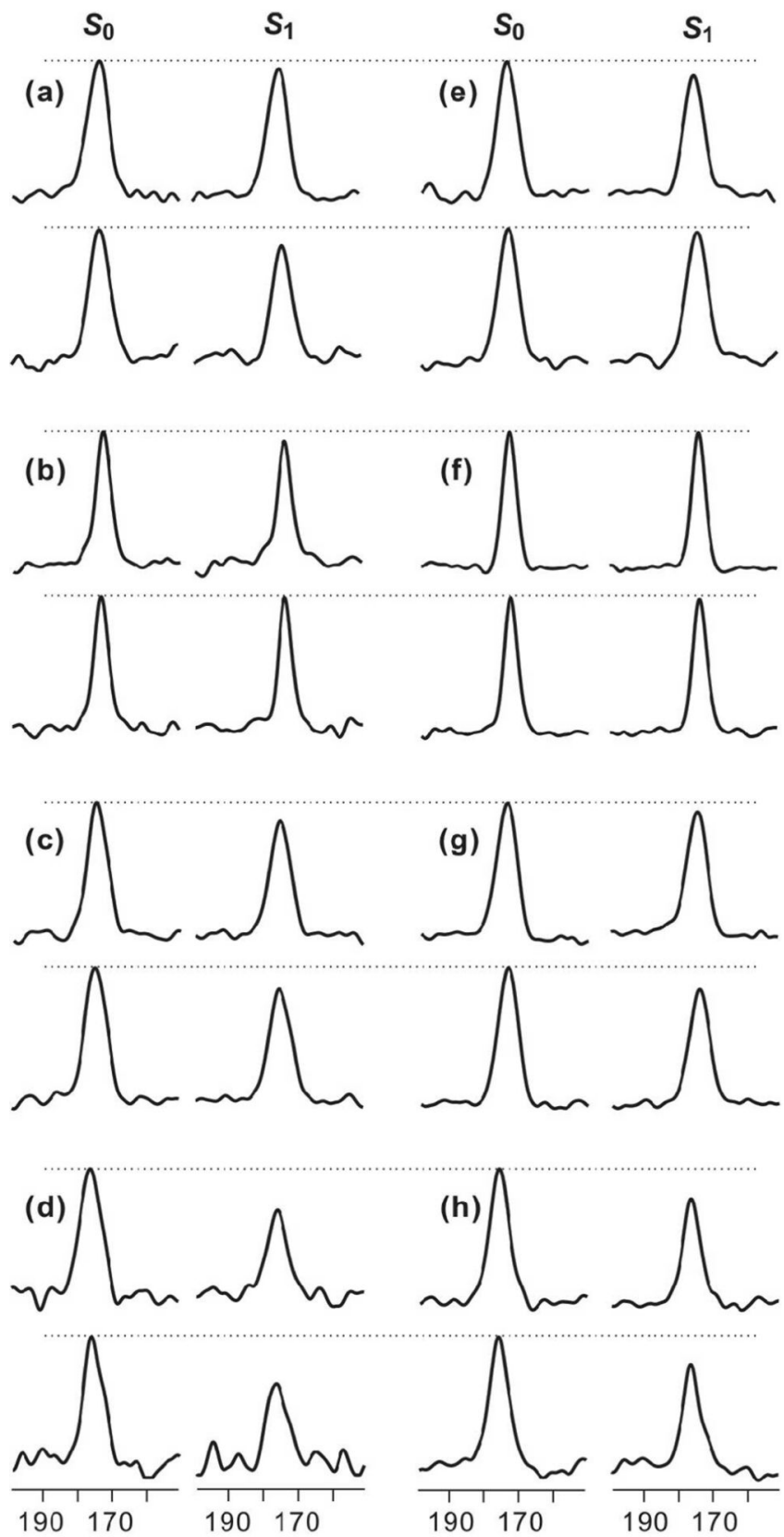

${ }^{13} \mathrm{C}$ Chemical Shift (ppm)

Figure 4.

${ }^{13} \mathrm{CO}-{ }^{31} \mathrm{P}$ REDOR spectra of membrane-associated HFP with peptide:lipid $\sim 0.04$. Each letter corresponds to a single sample which contained (a-d) PC:PG or (e-h) PC:PG:CHOL and (a, e) HFP2- ${ }^{5}$ GAL , (b, f) HFP3- ${ }^{8}$ FLG, (c, g) HFP2- ${ }^{11}$ FLG, or (d, h) HFP2- ${ }^{14}$ AAG. For each letter/ sample, $S_{0}$ (left), $S_{1}$ (right), $\tau=16 \mathrm{~ms}$ (top), and $\tau=24 \mathrm{~ms}$ (bottom) spectra are displayed. The dotted lines are drawn for visual comparison of $S_{0}$ and $S_{1}$ peak intensities. Each spectrum was processed with $300 \mathrm{~Hz}$ Gaussian line broadening and baseline correction. The numbers of $S_{0}$ or $S_{1}$ scans summed to obtain the top and bottom spectra were respectively: a, 30000, 56000; b, 27509, 29463; c, 20000, 40000; d, 44129, 48296; e, 8448, 52384; f, 5488, 21664; g, 28032, 52384; and h, 22576, 50240 . 

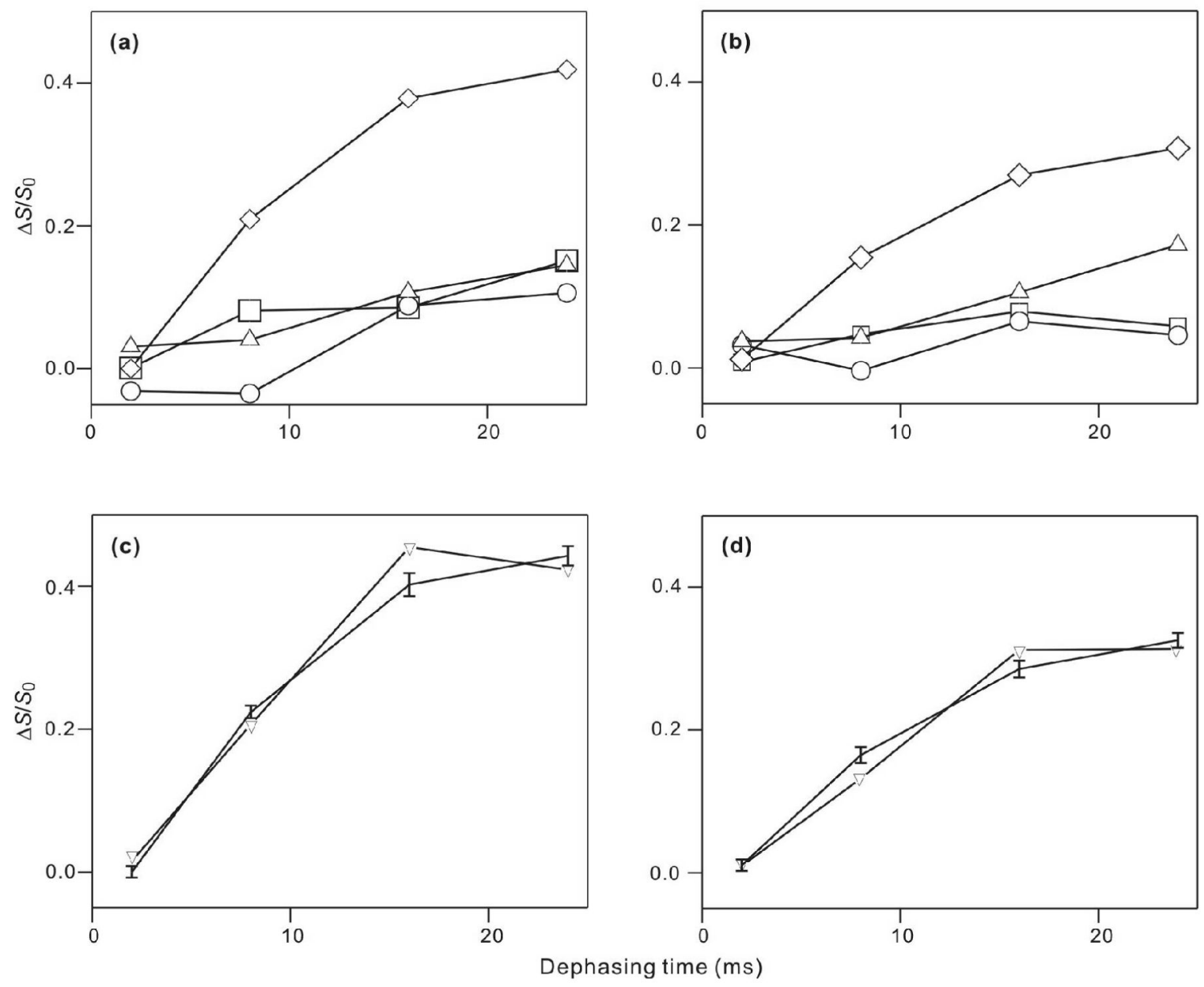

Figure 5.

$\left(\Delta S / S_{0}\right)$ vs dephasing time for membrane-associated HFP in (a,c) PC:PG or (b,d)

PC:PG:CHOL. For panels a and b, the points correspond to $\left(\Delta S / S_{0}\right)^{\exp }$ and the symbol legend is: squares, HFP2- ${ }^{5} \mathrm{GAL}$; circles, HFP3- ${ }^{8} \mathrm{FLG}$; up triangles, HFP2- ${ }^{11} \mathrm{FLG}$; and diamonds, HFP2- ${ }^{14}$ AAG. The vertical dimensions of each symbol approximately correspond to the \pm 1 $\sigma$ uncertainty limits. Lines are drawn between $\left(\Delta S / S_{0}\right)^{\exp }$ values with adjacent values of $\tau$. Each $\left(\Delta S / S_{0}\right)^{\exp }$ value was determined by integration of $10 \mathrm{ppm}$ regions of the $S_{0}$ and $S_{1}$ spectra. Panels $\mathrm{c}$ and $\mathrm{d}$ respectively correspond to the HFP2- ${ }^{14} \mathrm{AAG} / \mathrm{PC}: \mathrm{PG}$ and the HFP2- ${ }^{14} \mathrm{AAG} /$ PC:PG:CHOL samples and the points correspond to $\left(\Delta S / S_{0}\right)^{l a b}$ (vertical lines with error bars) and best-fit $\left(\Delta S / S_{0}\right)^{\operatorname{sim}}$ (down triangles). Lines are drawn between points with adjacent $\tau$ values. For plot c, the best-fit $d=91 \pm 8 \mathrm{~Hz}$ with corresponding $r=5.12 \pm 0.16 \AA, f=0.45 \pm 0.02$, and $\chi_{\text {min }}^{2}=5.0$. For plot d, the best-fit $d=85 \pm 6 \mathrm{~Hz}$ with corresponding $r=5.24 \pm 0.13 \AA$, $f=0.32$ \pm 0.02 , and $\chi_{\min }^{2}=3.8$. 

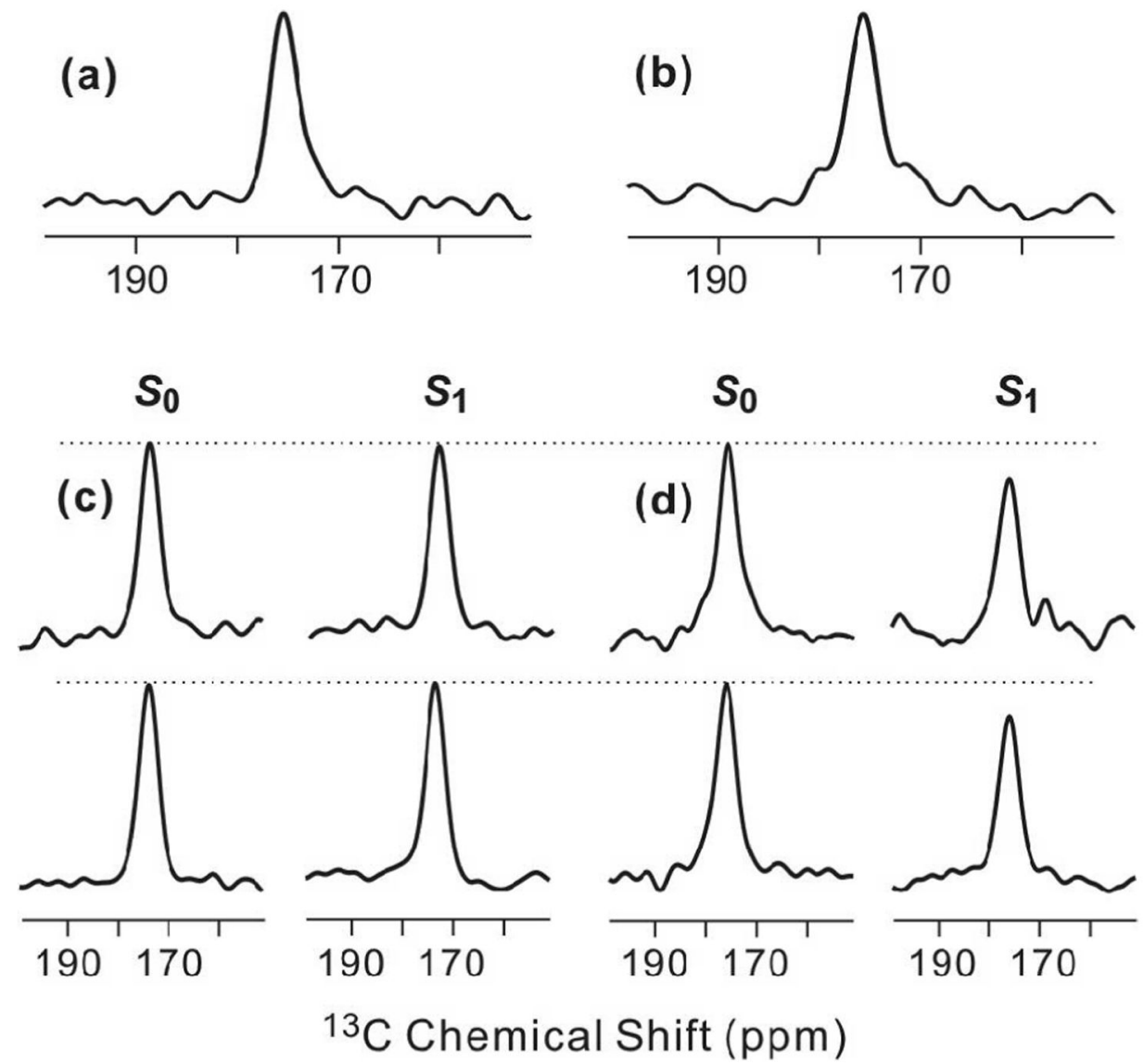

Figure 6.

${ }^{13} \mathrm{CO}-{ }^{31} \mathrm{P}$ REDOR spectra of $(\mathrm{a}, \mathrm{c}) \mathrm{HFP} 4-{ }^{6} \mathrm{~A} / \mathrm{PC}: \mathrm{PG}: \mathrm{CHOL}$ and $(\mathrm{b}, \mathrm{d}) \mathrm{HFP} 4-{ }^{14} \mathrm{~A} /$

PC:PG:CHOL samples with peptide:lipid $\sim 0.04$. Panels a and b are $S_{0}$ spectra obtained with $\tau=8 \mathrm{~ms}$ and were processed with $200 \mathrm{~Hz}$ Guassian line broadening and baseline correction. Panels c and d display $S_{0}$ (left), $S_{1}$ (right), $\tau=16 \mathrm{~ms}$ (top), and $\tau=24 \mathrm{~ms}$ (bottom) spectra. The dotted lines are drawn for visual comparison of $S_{0}$ and $S_{1}$ peak intensities. Each spectrum was processed with $300 \mathrm{~Hz}$ Gaussian line broadening and baseline correction. The numbers of $S_{0}$ or $S_{1}$ scans summed were: a, 2304; b, 3680; c, 5504 (top), 28288 (bottom); and d, 5120 (top), 28736 (bottom). 



Figure 7.

$\left(\Delta S / S_{0}\right)$ vs dephasing time for HFP4- ${ }^{6} \mathrm{~A} / \mathrm{PC}: \mathrm{PG}: \mathrm{CHOL}$ and HFP- ${ }^{14} \mathrm{~A} / \mathrm{PC}: \mathrm{PG}: \mathrm{CHOL}$ samples. In panel a, $\left(\Delta S / S_{0}\right){ }^{\text {exp }}$ points with error bars are displayed with legend: HFP4- ${ }^{6} \mathrm{~A}$, squares; and HFP4- ${ }^{14} \mathrm{~A}$, diamonds. Each $\left(\Delta S / S_{0}\right){ }^{\exp }$ value was determined from integrals of the entire $S_{0}$ and $S_{1}$ peaks. Panel b represents analysis of the HFP4- ${ }^{14}$ A data with legend: $\left(\Delta S / S_{0}\right)^{l a b}$, vertical lines with error bars; and best-fit $\left(\Delta S / S_{0}\right)^{\text {sim }}$, down triangles. Lines are drawn between points with adjacent $\tau$ values. The best-fit parameters were $d=93 \pm 10 \mathrm{~Hz}$ with corresponding $r=$ $5.08 \pm 0.19 \AA, f=0.29 \pm 0.02$, and $\chi_{\text {min }}^{2}=0.1$. 
(a)

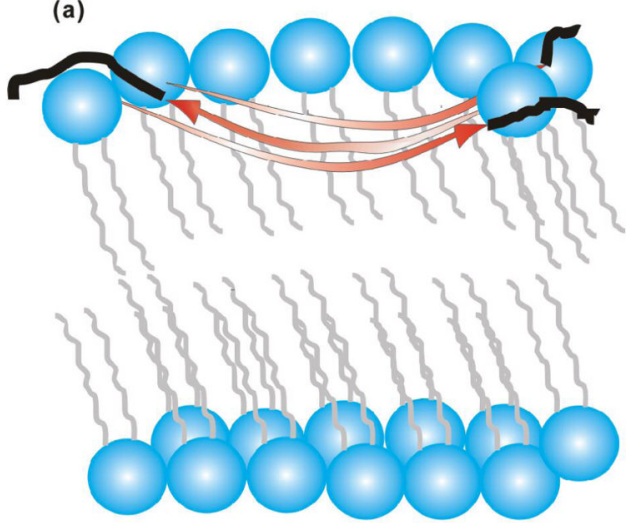

(b)
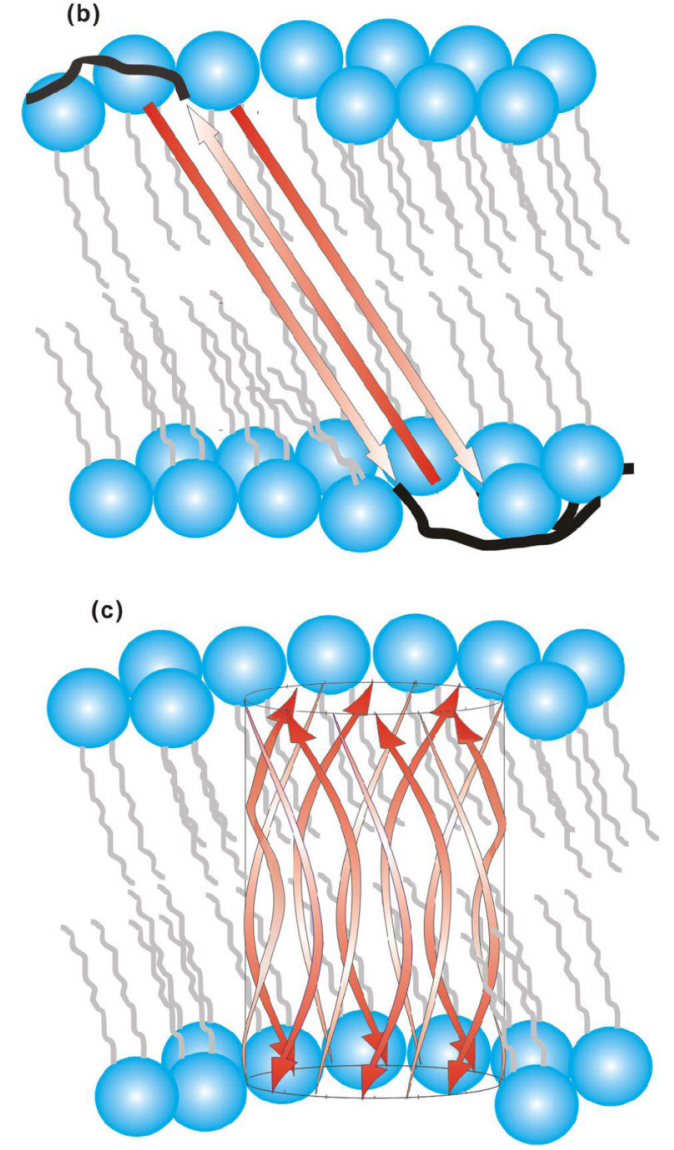

Figure 8.

(a) Partial membrane insertion (PMI) and (b, c) full membrane insertion (FMI) models for antiparallel $\beta$ strand HFP. The red arrows represent the A1 to G16 residues in strand conformation and the black lines represent the S17 to S23 residues in random coil conformations. For clarity, black lines are not displayed in c. Lipids are represented in blue and grey and cholesterol is not displayed. Three antiparallel strands are displayed in a, b and twelve strands are displayed in c but the actual number of strands in the oligomer/aggregate is not known. The curvature and angle of the strands with respect to the bilayer normal are not known but the models consider that A1-G16 has $55 \AA$ length and that the transbilayer distance is $\sim 48 \AA$ (100). The experiments do not provide information about the membrane locations of 
residues S17 to S23. relative to FMI model (b), the FMI $\beta$ barrel variant (c) could have reduced energy because all of the residues in the membrane interior have backbone hydrogen bonds. 